\title{
Breed of cow and herd productivity affect milk composition and modeling of coagulation, curd firming, and syneresis
}

\author{
G. Stocco, C. Cipolat-Gotet, T. Bobbo, A. Cecchinato, and G. Bittante \\ Department of Agronomy, Food, Natural Resources, Animals and Environment (DAFNAE) University of Padova (Padua), viale dell'Università 16, \\ 35020 Legnaro (PD), Italy
}

\begin{abstract}
Milk coagulation properties (MCP) have been widely investigated in the past using milk collected from different cattle breeds and herds. However, to our knowledge, no previous studies have assessed MCP in individual milk samples from several multi-breed herds characterized by either high or low milk productivity, thereby allowing the effects of herd and cow breed to be evaluated independently. Multi-breed herds (n $=41$ ) were classified into 2 categories based on milk productivity (high vs. low), defined according to the average milk net energy yielded daily by lactating cows. Milk samples were taken from 1,508 cows of 6 different breeds: 3 specialized dairy (Holstein-Friesian, Brown Swiss, Jersey) and 3 dual-purpose (Simmental, Rendena, Alpine Grey) breeds, and analyzed in duplicate (3,016 tests) using 2 lactodynamographs to obtain 240 curd firming $(\mathrm{CF})$ measurements over 60 min (1 every $15 \mathrm{~s})$ for each duplicate. The 5 traditional single-point MCP (RCT, $\mathrm{k}_{20}, \mathrm{a}_{30}, \mathrm{a}_{45}$, and $\mathrm{a}_{60}$ ) were yielded directly by the instrument from the available $\mathrm{CF}$ measures. All $240 \mathrm{CF}$ measures of each replicate were also used to estimate 4 individual equation parameters: RCT estimated according to curd firm change over time modeling $\left(\mathrm{RCT}_{\mathrm{eq}}\right)$, asymptotic potential curd firmness $\left(\mathrm{CF}_{\mathrm{P}}\right)$, curd firming instant rate constant $\left(\mathrm{k}_{\mathrm{CF}}\right)$, and syneresis instant rate constant $\left(\mathrm{k}_{\mathrm{SR}}\right)$ and 2 derived traits: maximum curd firmness achieved within $45 \min \left(\mathrm{CF}_{\max }\right)$ and time at achievement of $\mathrm{CF}_{\max }\left(\mathrm{t}_{\max }\right)$ by curvilinear regression using a nonlinear procedure. Results showed that the effect of herd-date on traditional and modeled MCP was modest, ranging from $6.1 \%$ of total variance for $\mathrm{k}_{20}$ to $10.7 \%$ for RCT, whereas individual animal variance was the highest, ranging from $32.0 \%$ for $t_{\max }$ to $82.5 \%$ for $\mathrm{RCT}_{\text {eq. }}$. The repeatability of MCP was high $(>80 \%)$ for all traits except those associated with the last part of the lactodynamographic curve (i.e., $\mathrm{a}_{60}$,
\end{abstract}

Received June 27, 2016.

Accepted September 17, 2016.

${ }^{1}$ Corresponding author: alessio.cecchinato@unipd.it
$\mathrm{k}_{\mathrm{SR}}, \mathrm{k}_{\mathrm{CF}}$, and $\mathrm{t}_{\max }: 57$ to $71 \%$ ). Reproducibility, taking into account the effect of instrument, was equal to or slightly lower than repeatability. Milk samples collected in farms characterized by high productivity exhibited delayed coagulation $\left(\mathrm{RCT}_{\mathrm{eq}}\right.$ : 18.6 vs. $\left.16.3 \mathrm{~min}\right)$ but greater potential curd firmness $\left(\mathrm{CF}_{\mathrm{P}}: 76.8\right.$ vs. 71.9 $\mathrm{mm}$ ) compared with milk samples collected from lowproductivity herds. Parity and days in milk influenced almost all MCP. Large differences in all MCP traits were observed among breeds, both between specialized and dual-purpose breeds and within these 2 groups of breeds, even after adjusting for milk quality and yield. Milk quality and MCP of samples from Jersey cows, and coagulation time of samples from Rendena cows were better than in milk from Holstein-Friesian cows, and intermediate results were found with the other breeds of Alpine origin. The results of this study, taking into account the intrinsic limitation of this technique, show that the effects of breed on traditional and modeled MCP are much greater than the effects of herd productivity class, parity, and DIM. Moreover, the variance in individual animals is much greater than the variance in individual herds within herd productivity class. It seems that improvement in MCP depends more on genetics (e.g., breed, selection) than on environmental and management factors.

Key words: milk coagulation, curd firming, syneresis, breed, herd productivity

\section{INTRODUCTION}

Milk coagulation properties (MCP) have consequences for cheese making, cheese yields, and cheese quality. The major cheese-making problems are fast coagulation of milk (acid, fermented milk), late or absence of coagulation of milk (especially with some milk protein genetic variants), weak curd firmness at cutting and slow syneresis of curd. Recently, Cecchinato and Bittante (2016) found strong relationships between cheese yield and curd firming patterns. Milk renneting properties also affect cheese quality (Horne and Banks, 2004), and are therefore particularly important for Protected Designation of Origin (PDO) cheeses (Mariani 
and Battistotti, 1999; Bertoni et al., 2005; Bittante et al., 2011).

Several techniques can be used to assess MCP (Klandar et al., 2007), but the most common approach used in both the laboratory and industry is lactodynamography. Traditionally, 3 single-point traits are recorded: rennet coagulation time (RCT, min), time to a curd firmness (CF) of $20 \mathrm{~mm}\left(\mathbf{k}_{\mathbf{2 0}}, \mathrm{min}\right)$, and $\mathrm{CF} 30 \mathrm{~min}$ after enzyme addition $\left(\mathbf{a}_{\mathbf{3 0}}, \mathrm{mm}\right)$.

The major limitations of the traditional MCP are the incidence of samples not coagulating (NC) within 30 min (no RCT, $\mathrm{k}_{20}$, or $\mathrm{a}_{30}$ available), the much greater incidence of late-coagulating (LC) samples that fail to reach $\mathrm{CF}$ of $20 \mathrm{~mm}$ (no $\mathrm{k}_{20}$ available), and the high correlation between $\mathrm{RCT}$ and $\mathrm{a}_{30}$ (so that the latter trait has limited informative value).

Recently, a more informative method to overcome, at least in part, the above-mentioned limitations and acquire detailed information is to model the curd-firming process over time $\left(\mathbf{C F}_{\mathbf{t}}\right)$ using the hundreds of singlepoint pieces of information automatically available for each milk sample analyzed (Bittante, 2011), and to extend the lactodynamographic test period beyond 30 min (Bittante et al., 2013).

Traditional MCP obtained from lactodynamographs have been used in several studies to compare milk from cows of different breeds, as reviewed by Bittante et al. (2012). Comparisons are difficult, however, because they are often based on a small number of cows of 2 to 3 different breeds reared in one (experimental) farm (Auldist et al., 2002; Jõudu et al., 2008), or on a large number of cows from many single-breed farms (Poulsen et al., 2013), so that the effect of breed is confounded with the effects of farm, feeding strategy, and sampling date, or they are based on bulk milk samples from different single-breed farms (Mariani et al., 1984; De Marchi et al., 2007). In addition, the effect of feeding strategy is not well known as experimental trials focus on some specific diet ingredient (Kreuzer et al., 1996; Malossini et al., 1996), and very few studies have been carried out at the population level (Tyrisevä et al., 2003).

Over time, dairy farms have moved toward larger and more industrialized setups in which cows are fed highenergy diets, and dairy herds have changed in terms of the proportions and productivity of breeds, and dairy breeds have been assiduously selected to improve productivity and milk quality.

We have carried out a large study involving several multi-breed herds characterized by variable levels of productivity, which allows for independent evaluation of the effects of farm and of different cattle breeds. The specific aims of this study were (1) to quantify and characterize the effects on MCP of high or low herd productivity (defined according to the milk net energy yielded daily by the cows); (2) to quantify the variability of herds within herd productivity class; (3) to make a within-herd comparison of 3 dairy and 3 dual-purpose breeds for their milk quality, traditional $\mathrm{MCP}$, and modeled $\mathrm{CF}_{\mathrm{t}}$; and (4) to quantify the effects of DIM and parity, and assess the repeatability and reproducibility of traditional $\mathrm{MCP}$ and $\mathrm{CF}_{\mathrm{t}}$ modeled and derived traits.

\section{MATERIALS AND METHODS}

\section{Multi-Breed Herds}

The present study is part of the Cowplus project. A total of 1,508 cows from 41 multi-breed herds (2 to 5 breeds, with an average of 3.0) located in the Trentino Alto Adige region of the northeastern Italian Alps, were controlled once for daily milk production and sampled during the evening milking for milk quality analyses. A total of 6 breeds were sampled - 3 specialized dairy breeds: Holstein Friesian (HF, 31 herds and 471 cows), Brown Swiss (BS, 36 herds, 663 cows), and Jersey (Je, 7 herds, 40 cows); and 3 dual-purpose breeds: Simmental (Si, 20 herds, 158 cows), and 2 autochthonous breeds, Alpine Grey (AG, 13 herds, 73 cows) and Rendena (Re, 8 herds, 103 cows). The herds comprised 15 combinations of breeds: $\mathrm{HF}+\mathrm{BS}+\mathrm{Si}(\mathrm{n}=8$ herds), $\mathrm{HF}+\mathrm{BS}(\mathrm{n}=7$ herds $), \mathrm{BS}+\mathrm{Si}+\mathrm{AG}(\mathrm{n}=6$ herds $)$, $\mathrm{HF}+\mathrm{BS}+\mathrm{Re}(\mathrm{n}=3$ herds $), \mathrm{HF}+\mathrm{BS}+\mathrm{Je}(\mathrm{n}=3$ herds), $\mathrm{BS}+\mathrm{AG}(\mathrm{n}=3$ herds), $\mathrm{HF}+\mathrm{BS}+\mathrm{Si}+\mathrm{AG}$ ( $\mathrm{n}=2$ herds $), \mathrm{HF}+\mathrm{AG}(\mathrm{n}=2$ herds $), \mathrm{BS}+\mathrm{Je}(\mathrm{n}=$ 1 herds), $\mathrm{HF}+\mathrm{BS}+\mathrm{Si}+\mathrm{AG}+\mathrm{Re}(\mathrm{n}=1$ herd $), \mathrm{BS}$ $+\mathrm{Si}+\mathrm{AG}+\operatorname{Re}(\mathrm{n}=1$ herd $), \mathrm{HF}+\mathrm{Si}+\operatorname{Re}(\mathrm{n}=1$ herd $), \mathrm{BS}+\mathrm{AG}+\operatorname{Re}(\mathrm{n}=1$ herd $), \mathrm{HF}+\mathrm{Si}(\mathrm{n}=1$ herd), and $\mathrm{HF}+\operatorname{Re}(\mathrm{n}=1$ herd $)$.

\section{Dairy and Dual-Purpose Breeds}

The 41 mixed-breed dairy farms selected for the study had only cows enrolled in the Italian Herd Books of the 6 breeds studied and were practicing almost exclusively AI using national or imported semen from proven bulls or progeny testing young bulls.

The dairy large-framed Holstein Friesian cows in the province of Trento were obtained from semen mainly from Italian, German, American, and Dutch bulls (Cecchinato et al., 2015a). In this study, the cows were characterized by a BW of $654 \pm 45 \mathrm{~kg}$, a parity of 2.4 \pm 1.6 , and DIM of $197 \pm 140$.

The dairy large-framed Brown Swiss cows were obtained from semen from Italian, Austrian, German, American, and Swiss bulls. Body size was very close to that of Holstein Friesians $(656 \pm 46 \mathrm{~kg})$, as was parity $(2.6 \pm 1.6)$ and DIM $(188 \pm 139)$. 
The dairy small-framed Jersey breed has been recently introduced, and the cows came from semen imported mainly from the United States and Denmark. Body size was very small $(413 \pm 37 \mathrm{~kg})$, whereas the other characteristics were similar to those of the other 2 specialized dairy breeds (parity $2.9 \pm 2.1$, DIM 214 $\pm 116)$.

The large-framed Simmental cows in the area belong to the dual-purpose strains of this breed reared mainly in the Alpine regions, and came from inseminations using semen from Italian, German, and Austrian bulls, as well as from French Montbéliarde bulls. Sires are often preselected for growth rate and muscularity through station performance testing, and the body size of the cows was only slightly greater than that of the 2 largeframed dairy breeds $(662 \pm 56 \mathrm{~kg})$, as was parity $(2.7$ $\pm 1.9)$, whereas DIM was lower $(177 \pm 118)$.

The medium-framed local breeds, Rendena and Alpine Grey, are both dual-purpose breeds of Alpine origin. Bulls are selected in 2 steps, with preselection based on station performance testing (Andersen et al., 1981). The Rendena breed has a dark chestnut coat, and the Alpine Grey has a gray coat; both are of medium size (565 \pm 48 and $527 \pm 45 \mathrm{~kg}$, respectively). They are similar to the Simmental breed in parity $(2.8$ \pm 1.8 and $2.5 \pm 1.7)$ and DIM $(189 \pm 94$ and $158 \pm 75)$.

\section{Herd Productivity Classification}

The herds were classified into 2 categories of productivity (HP), defined according to the average daily milk energy output (dMEO) of the lactating cows. The net energy content $\left(\mathrm{NE}_{\mathrm{L}}\right)$ of milk was estimated with the following equation, proposed by the NRC (2001):

$$
\begin{gathered}
\mathrm{NE}_{\mathrm{L}}(\mathrm{Mcal} / \mathrm{kg})=0.0929 \times \text { fat }, \%+0.0547 \\
\times \text { protein, } \%+0.0395 \times \text { lactose }, \%,
\end{gathered}
$$

where $\mathrm{NE}_{\mathrm{L}}$ is the energy of $1 \mathrm{~kg}$ of milk. The $\mathrm{NE}_{\mathrm{L}}$ values obtained were converted to megajoules per kilogram and multiplied by the daily milk yield of each cow $(\mathrm{MJ} / \mathrm{d})$ to obtain the individual dMEO of each cow. Individual dMEO data were subjected to an ANOVA using the GLM procedure in SAS (SAS Institute Inc., Cary, NC) to estimate the least squares means (LSM) of the dMEO for the selected herds after correcting for breed, DIM, and parity of the cows. After ranking the dMEO LSM of the 41 farms, we divided the herds into high producing (high HP: $\mathrm{n}=20$, average dMEO = $90.86 \mathrm{MJ} / \mathrm{d}$ ) and low producing (low HP: $\mathrm{n}=21$, average $\mathrm{dMEO}=56.35 \mathrm{MJ} / \mathrm{d}$ ) based on the median value.

Large-framed breeds ( $\mathrm{HF}, \mathrm{BS}$, and $\mathrm{Si}$ ) were found in herds of both high and low productivity, Jerseys only in high-HP herds, and local breeds (Re and AG) only in low-HP herds.

\section{Analysis of Milk Samples}

Milk samples (without preservative) were adjusted to $4^{\circ} \mathrm{C}$ immediately after collection and processed within $24 \mathrm{~h}$ of sampling at the Milk Quality Laboratory of the Department of Agronomy, Food, Natural Resources, Animals and Environment (DAFNAE) of the University of Padua.

All samples were analyzed for $\mathrm{pH}$ (Crison Basic 25 portable pH meter; Crison Instruments SA, Barcelona, Spain), and SCC (Fossomatic Minor, Foss Electric A/S, Hillerød, Denmark). Milk SCC was log-transformed to SCS (Ali and Shook, 1980). Protein, fat, and lactose contents were measured by a Milkoscan FT2 infrared analyzer (Foss Electric A/S) calibrated according to reference methods: ISO 8968-2/IDF 20-2 for protein (ISO-IDF, 2014), ISO 1211/IDF for fat (ISO-IDF, 2010a), ISO 26462/IDF 214 (ISO-IDF, 2010b) for lactose.

Milk coagulation properties were measured in duplicate using mechanical lactodynamographs (2 instruments; Formagraph, Foss Electric A/S) with pendulum calibration carried out before each session of the trial. For each animal replicate, $10 \mathrm{~mL}$ of milk, heated to $35^{\circ} \mathrm{C}$, was mixed with $200 \mu \mathrm{L}$ of rennet solution (Hansen Standard 215 with $80 \pm 5 \%$ chymosin and $20 \pm 5 \%$ pepsin; Pacovis Amrein AG, Bern, Switzerland) freshly diluted to $1.2 \%$ (wt/vol) in distilled water. Traditional single-point measurements of each milk sample (RCT, min; $\mathrm{k}_{20}$, min; and $\mathrm{a}_{30}, \mathrm{a}_{45}$, and $\mathrm{a}_{60}, \mathrm{~mm}$ ) were obtained directly from the instruments. A data file of the $240 \mathrm{CF}$ observations (1 every $15 \mathrm{~s}$ for the $60 \mathrm{~min}$ of the test) for each milk replicate was also extracted.

\section{Modeling Curd Firmness and Syneresis}

The 4-parameter model (Bittante et al., 2013) was chosen for this study because a preliminary view of the $\mathrm{CF}_{\mathrm{t}}$ data showed an appreciable decrease in $\mathrm{CF}$ in the final part of the curve of many milk samples. It uses all the information available for estimating the 4 parameters, which, unlike traditional MCP, are not single-point measurements. The model tested was

$$
\mathrm{CF}_{\mathrm{t}}=\mathrm{CF}_{\mathrm{P}} \times\left[1-e^{-\mathrm{k}_{\mathrm{CF}} \times\left(\mathrm{t}-\mathrm{RCT}_{\mathrm{eq}}\right)}\right] \times e^{-\mathrm{k}_{\mathrm{SR}} \times\left(\mathrm{t}-\mathrm{RCT}_{\mathrm{eq}}\right)},
$$

where $\mathrm{CF}_{\mathrm{t}}$ is curd firmness at time $\mathrm{t}(\mathrm{mm}) ; \mathbf{C F}_{\mathbf{P}}$ is the asymptotical potential value of $\mathrm{CF}$ at an infinite time $(\mathrm{mm}) ; \mathbf{k}_{\mathrm{CF}}$ is the curd-firming instant rate constant (\% 
$\left.\times \min ^{-1}\right) ; \mathbf{k}_{\mathrm{SR}}$ is the syneresis instant rate constant $\left(\% \times \min ^{-1}\right)$; and $\mathbf{R C T}_{\text {eq }}$ is RCT estimated by $\mathrm{CF}_{\mathrm{t}}$ equation on the basis of all data points (min). The $\mathrm{CF}_{\mathrm{P}}$ is conceptually independent of test duration and is not intrinsically dependent on RCT (unlike $\mathrm{a}_{30}$ ). The parameter $\mathrm{k}_{\mathrm{CF}}$ describes the shape of the curve from the time of milk gelation to infinity and is conceptually different from $\mathrm{k}_{20}$ because it uses all available information. The parameter $\mathrm{k}_{\mathrm{SR}}$ is the curd syneresis instant rate constant $\left(\% \times \min ^{-1}\right)$. The parameter $\mathrm{k}_{\mathrm{CF}}$ is assumed to increase $\mathrm{CF}$ toward the asymptotic value of $\mathrm{CF}_{\mathrm{P}}$, whereas $\mathrm{k}_{\mathrm{SR}}$ is assumed to decrease CF toward a null asymptotic value. In the initial phase of the test, the first rate constant prevails over the second, such that $\mathrm{CF}_{\mathrm{t}}$ increases to a point in time $\left(\mathbf{t}_{\max }\right)$ at which the effects of the 2 parameters are equal but opposite in sign; this is when $\mathrm{CF}_{\mathrm{t}}$ attains its maximum level $\left(\mathbf{C F}_{\text {max }}\right)$. Thereafter, $\mathrm{CF}_{\mathrm{t}}$ decreases, tending toward a null value due to the effect of curd syneresis and the corresponding expulsion of whey. The $\mathrm{RCT}_{\mathrm{eq}}$ parameter has the same meaning as the traditional RCT measure but was estimated using all available data.

\section{Statistical Analysis}

To avoid convergence and estimation problems, the procedure (Bittante et al., 2013) was modified to include CF measurements up to 45 min from the addition of rennet (180 records for each individual milk sample, 1 every $15 \mathrm{~s}$ ), whereas $\mathrm{CF}_{\mathrm{P}}$ was calculated by multiplying $\mathrm{CF}_{\max }$ by 1.34 , the coefficient resulting from the linear regression between $\mathrm{CF}_{\mathrm{P}}$ and $\mathrm{CF}_{\max }$ values obtained in a preliminary analysis. The other $3 \mathrm{CF}_{\mathrm{t}}$ model parameters $\left(\mathrm{RCT}_{\mathrm{eq}}, \mathrm{k}_{\mathrm{CF}}\right.$, and $\left.\mathrm{k}_{\mathrm{SR}}\right)$ were estimated by curvilinear regression using the nonlinear procedure (PROC NLIN) in SAS software (SAS Institute Inc., Cary, NC). The parameters of each individual equation were estimated using the Marquardt iterative method (350 iterations and a $10^{-5}$ level of convergence) according to Bittante (2011).

Experimental data from traditional and modeled MCP (2 replicates per cow) were analyzed using the MIXED procedure (SAS Institute Inc., Cary, NC) according to the following base model:

$$
\begin{aligned}
& y_{i j k l m n o p q}=\mu+H P_{m}+\operatorname{Herd}_{n}(H P)_{m} \\
& + \text { Breed }_{k}+\text { Parity }_{j}+\text { Breed }_{k} \times \text { Parity }_{j}+H P_{m} \\
& \times \text { Parity }_{j}+\text { DIM }_{i}+H P_{m} \times D I_{i}+\text { Animal }_{l} \\
& + \text { Instrument }_{o}+\text { Pendulum }_{p}\left(\text { Instrument }_{o}+e_{i j k l m n o p q}\right. \text {, }
\end{aligned}
$$

where $y_{i j k l m n o p q}$ is the observed trait $\left(\mathrm{RCT}, \mathrm{k}_{20}, \mathrm{a}_{30}, \mathrm{a}_{45}\right.$, $\left.\mathrm{a}_{60}, \mathrm{RCT}_{\mathrm{eq}}, \mathrm{CF}_{\mathrm{P}}, \mathrm{k}_{\mathrm{CF}}, \mathrm{k}_{\mathrm{SR}}, \mathrm{CF}_{\max }, \mathrm{t}_{\max }\right) ; \mu$ is the overall intercept of the model; $H P_{m}$ is the fixed effect of the $m$ th herd productivity $\left(m=2\right.$ levels); $\operatorname{Herd}_{n}(H P)_{m}$ is the random effect of the $n$th herd ( $n=1$ to 41$)$ within the $m$ th class of herd productivity; Breed $_{k}$ is the fixed effect of the $k$ th breed ( $k=\mathrm{HF}$, BS, Je, Si, AG and Re); Parity $y_{j}$ is the fixed effect of the $j$ th parity $(j=1$ to $\geq 4)$; $D I M_{i}$ is the fixed effect of the ith class of days in milk $[i=1$ to 11 ; class $1,5-35$ d (324 samples); class $2,36-65$ d (254 samples); class 3, 66-95 d (256 samples); class 4, 96-125 d (274 samples); class 5, 126-155 d (250 samples); class 6, 156-185 d (238 samples); class 7, 186-215 d (244 samples); class 8, 216-245 d (262 samples); class 9, 246-275 d (246 samples); class 10, 276-305 d (184 samples); class 11, >305 d (482 samples)]; Animal is the random effect of the $l$ th animal $(l=1$ to 1,508$)$; Instrument ${ }_{o}$ is the random effect of the oth instrument ( $o=2$ instruments); Pendulum ${ }_{p}$ is the random effect of the $p$ th pendulum ( $p=1$ to 10 ) within the oth instrument; and $e_{i j k l m n o p q}$ is the random residual $\sim N\left(0, \sigma_{e}^{2}\right)$.

The milk yield (MY) and chemical components of milk (1 observation per cow) were analyzed using the same model without Animal, Instrument, and Pendulum(Instrument) as random factors (reduced model).

A model that also included the breed $\times$ herd productivity interaction (interaction model) was fitted to test the data from the $3 \mathrm{HF}$, BS, and Si breeds present in both classes of herds. As this interaction was almost never significant, or, when significant, was not relevant, the results of this model analysis are not shown nor discussed. The breed $\times$ DIM interaction was not included in the model because of the low number of observations in some cells of the less-represented breeds.

A further model (extended model) was used to analyze the direct effects of breed on MCP and $\mathrm{CF}_{\mathrm{t}}$ traits corrected for MY and quality traits and was obtained from the base model with inclusion of linear covariate of MY, fat \%, protein \%, lactose \%, pH, and SCS. Moreover, the breed effect was considered random to obtain a correct quantification of breed variance. The indirect effect of breed on $\mathrm{MCP}$ and $\mathrm{CF}_{\mathrm{t}}$ traits due to breed differences in terms of MY and quality was obtained by subtracting the breed variance yielded by the extended model from the breed variance obtained from the base model (with breed as random effect). Both direct and indirect breed variance were represented as percentage of total breed variance.

Orthogonal contrasts were estimated between the LSM of traits for the effect of breed: (1) dairy specialized (HF, BS, and Je) versus dual-purpose breeds ( $\mathrm{Si}, \mathrm{AG}$, and Re); (2) within specialized, large-framed versus small-framed breeds ( $\mathrm{HF}+\mathrm{BS}$ vs. Je); (3) comparison of the 2 large-framed dairy breeds (HF vs. BS); 
(4) within dual-purpose, large-framed breed versus medium-framed local breeds (Si vs. Re $+\mathrm{AG}$ ); and (5) comparison of the 2 medium-framed local dual-purpose breeds (Re vs. AG). Orthogonal contrasts were also estimated between the LSM of traits for the effect of parity: parity 1 versus parity $\geq 2$; parity 2 versus parity $\geq 3$; and parity 3 versus parity $\geq 4$.

\section{RESULTS}

\section{Milk Quality and Coagulative Ability}

Descriptive statistics of MY, chemical composition, traditional MCP, and curd firming modeling $\left(\mathrm{CF}_{\mathrm{t}}\right)$ equation parameters of the milk samples are summarized in Table 1. All traits except $\mathrm{pH}$ and lactose exhibited high variability due to the diversity of herd productivity and the 6 sampled breeds. The coefficient of variation of traditional and modeled MCP varied between $17 \%$ for $\mathrm{t}_{\max }$ and $64 \%$ for $\mathrm{k}_{20}$.

\section{Effects of Animal and Herd-Date, Repeatability, and Reproducibility}

Variances in single test-day MY, milk quality, traditional $\mathrm{MCP}$, and $\mathrm{CF}_{\mathrm{t}}$ equation parameters are summarized in Table 2. Regarding MY and chemical composition, the proportion of variance due to herddate was very large for $\mathrm{pH}$, followed by $\mathrm{MY}$, whereas the incidence of the effect of herd-date on the other traits was smaller (8.9\% for lactose content to $24.6 \%$ for protein content). As these traits were not analyzed in duplicate, the proportion of the total variance listed as animal also includes the residual component.

In the case of traditional and modeled MCP, among the random effects, herd-date was modest compared with the same effect on milk production and quality, which varied from $6.1 \%$ for $\mathrm{k}_{20}$ to $10.7 \%$ for $\mathrm{RCT}$. The individual effect had the highest variance, from 61.3 to $82.5 \%$ for the majority of the traits considered $(7 / 11)$, but was lower only for the traits recorded mainly in the last part of the curve $(5 / 11)$. Instrument had very little effect on variability in the renneting properties of milk (from $0.0 \%$ for the time measurements to $4.7 \%$ of the total variance for $\mathrm{a}_{60}$, data not shown), whereas pendulum within instrument affected results more than instrument, with a range from $1.0 \%$ for the $2 \mathrm{RCT}$ traits to $13.6 \%$ for $\mathrm{k}_{\mathrm{CF}}$ (data not shown). Repeatability was very good ( 81.7 to $94.1 \%$ ) for the majority of traits analyzed $(7 / 11)$, but less so in the 5 traits recorded in the last part of the $\mathrm{CF}_{\mathrm{t}}$ curve $\left(57.1 \%\right.$ for $\mathrm{t}_{\max }$ to $70.7 \%$ for $\mathrm{a}_{60}$ ). Reproducibility was equal to or slightly lower

Table 1. Descriptive statistics of milk yield, chemical composition, traditional coagulation properties, and curd firming time $\left(\mathrm{CF}_{\mathrm{t}}\right)$ equation parameters and derived traits

\begin{tabular}{|c|c|c|c|c|c|}
\hline \multirow[b]{2}{*}{ Trait } & \multirow{2}{*}{$\begin{array}{c}\text { No. of } \\
\text { samples }\end{array}$} & \multirow[b]{2}{*}{ Mean } & \multirow[b]{2}{*}{ SD } & \multicolumn{2}{|c|}{ Percentile } \\
\hline & & & & $1 \mathrm{st}$ & 99th \\
\hline Milk yield, kg/d & 1,489 & 24.3 & 9.1 & 6.0 & 49.0 \\
\hline \multicolumn{6}{|c|}{ Chemical composition of milk } \\
\hline Protein, \% & 1,490 & 3.70 & 0.44 & 2.89 & 4.71 \\
\hline Fat, \% & 1,480 & 4.27 & 1.10 & 1.88 & 6.94 \\
\hline Lactose, \% & 1,502 & 4.98 & 0.29 & 4.10 & 5.52 \\
\hline $\mathrm{pH}$ & 1,488 & 6.51 & 0.10 & 6.28 & 6.73 \\
\hline $\mathrm{SCS}^{1}$ & 1,495 & 2.85 & 1.86 & -0.47 & 7.28 \\
\hline \multicolumn{6}{|c|}{ Traditional coagulation properties $^{2}$} \\
\hline $\mathrm{RCT}, \min$ & 2,888 & 18.6 & 6.9 & 8.15 & 43.15 \\
\hline $\mathrm{k}_{20}, \min$ & 2,851 & 4.2 & 2.7 & 1.30 & 14.30 \\
\hline $\mathrm{a}_{30}, \mathrm{~mm}$ & 2,889 & 40.1 & 19.0 & 0.00 & 72.40 \\
\hline $\mathrm{a}_{45}, \mathrm{~mm}$ & 2,902 & 51.8 & 15.2 & 2.32 & 77.88 \\
\hline $\mathrm{a}_{60}, \mathrm{~mm}$ & 2,910 & 54.2 & 13.7 & 17.54 & 79.54 \\
\hline \multicolumn{6}{|c|}{$\mathrm{CF}_{\mathrm{t}}$ equation parameters ${ }^{3}$} \\
\hline $\mathrm{RCT}_{\mathrm{eq}}, \min$ & 2,886 & 18.9 & 7.0 & 7.94 & 43.60 \\
\hline $\mathrm{k}_{\mathrm{CF}}, \% \times \min ^{-1}$ & 2,888 & 8.1 & 2.5 & 4.64 & 14.90 \\
\hline $\mathrm{k}_{\mathrm{SR}}, \% \times \min ^{-1}$ & 2,884 & 0.63 & 0.23 & 0.00 & 1.31 \\
\hline $\mathrm{CF}_{\mathrm{P}}, \mathrm{mm}$ & 2,914 & 74.5 & 17.4 & 23.35 & 106.2 \\
\hline $\mathrm{CF}_{\max }, \mathrm{mm}$ & 2,914 & 55.6 & 13.0 & 17.42 & 79.25 \\
\hline $\mathrm{t}_{\max }, \min$ & 2,930 & 51.9 & 8.9 & 28.00 & 60.0 \\
\hline
\end{tabular}

${ }^{1} \mathrm{SCS}=3+\log _{2}(\mathrm{SCC} / 100,000)$.

${ }^{2} \mathrm{RCT}=$ measured rennet gelation time; $\mathrm{k}_{20}=$ time interval between gelation and attainment of curd firmness of $20 \mathrm{~mm} ; \mathrm{a}_{30}\left(\mathrm{a}_{45}, \mathrm{a}_{60}\right)=$ curd firmness after $30(45,60)$ min from rennet addition.

${ }^{3} \mathrm{RCT}_{\mathrm{eq}}=\mathrm{RCT}$ estimated according to curd firm change over time modeling $\left(\mathrm{CF}_{\mathrm{t}}\right) ; \mathrm{k}_{\mathrm{CF}}=$ curd firming instant rate constant; $\mathrm{CF}_{\mathrm{P}}=$ asymptotic potential curd firmness; $\mathrm{k}_{\mathrm{SR}}=$ syneresis instant rate constant; $\mathrm{CF}_{\max }=$ maximum curd firmness achieved within $45 \mathrm{~min} ; \mathrm{t}_{\max }=$ time at achievement of $\mathrm{CF}_{\max }$. 
Table 2. Variance of the random effects, repeatability, and reproducibility of traditional milk coagulation properties and of curd firming modeling $\left(\mathrm{CF}_{\mathrm{t}}\right)$ equation parameters

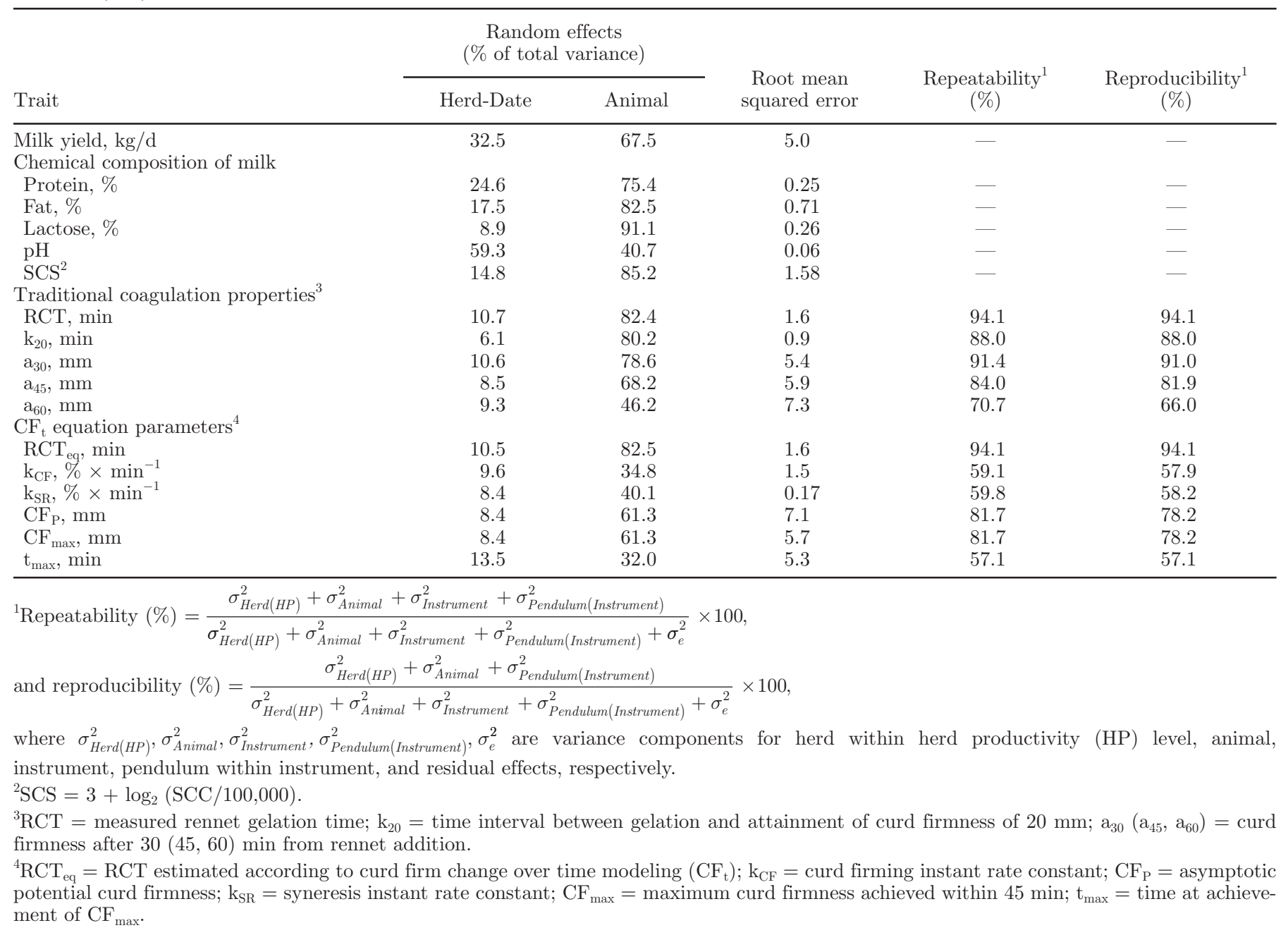

than repeatability, because of the low effect of instrument on these traits.

\section{Effects of Herd Productivity and Parity}

Least squares means of HP and parity, and $F$-values of the same factors of variation and of the $\mathrm{HP} \times$ parity and HP $\times$ DIM interactions are summarized in Table 3. Milk yield was obviously very different in the 2 herd productivity categories, and milk protein and fat contents were higher in high HP than in low HP, whereas lactose, $\mathrm{pH}$, and SCS were almost identical in the 2 groups.

Parity affected both milk production and quality, except for fat content. Least squares means of classes of parity showed that MY increased from the first to later lactations, as expected, whereas the opposite trend was noted for protein content. It is also worthwhile noting (data not shown) that the milk yield of cows reared in the high-HP farms increased from the first to third lactation by an average of $3.7 \mathrm{~kg} / \mathrm{d}$, whereas that of cows reared in the low-HP farms increased by only 2.2 $\mathrm{kg} / \mathrm{d}(\mathrm{HP} \times$ parity interaction: $P<0.001)$, although these increases represent almost the same proportion of primiparous daily yield $(+15 \%$ and $+14 \%$ for high HP and low HP, respectively). Acidity and SCS of milk tended to increase almost linearly across classes of parity, whereas lactose showed an almost opposite trend. The HP $\times$ parity interaction affected lactose slightly $(P$ $<0.05)$ but SCS content greatly because the cell content of milk from cows reared in high-HP farms (data not shown) increased by $57 \%$ from first to third lactation, whereas SCS of milk from low-HP farms increased only by $8 \%(\mathrm{HP} \times$ parity interaction: $P<0.001)$.

Regarding traditional MCP, milk samples from farms characterized by high HP presented delayed RCT, although curd firmness was higher 60 min after rennet addition compared with milk samples from low- 
BREED, HERD PRODUCTIVITY, AND MILK COMPOSITION

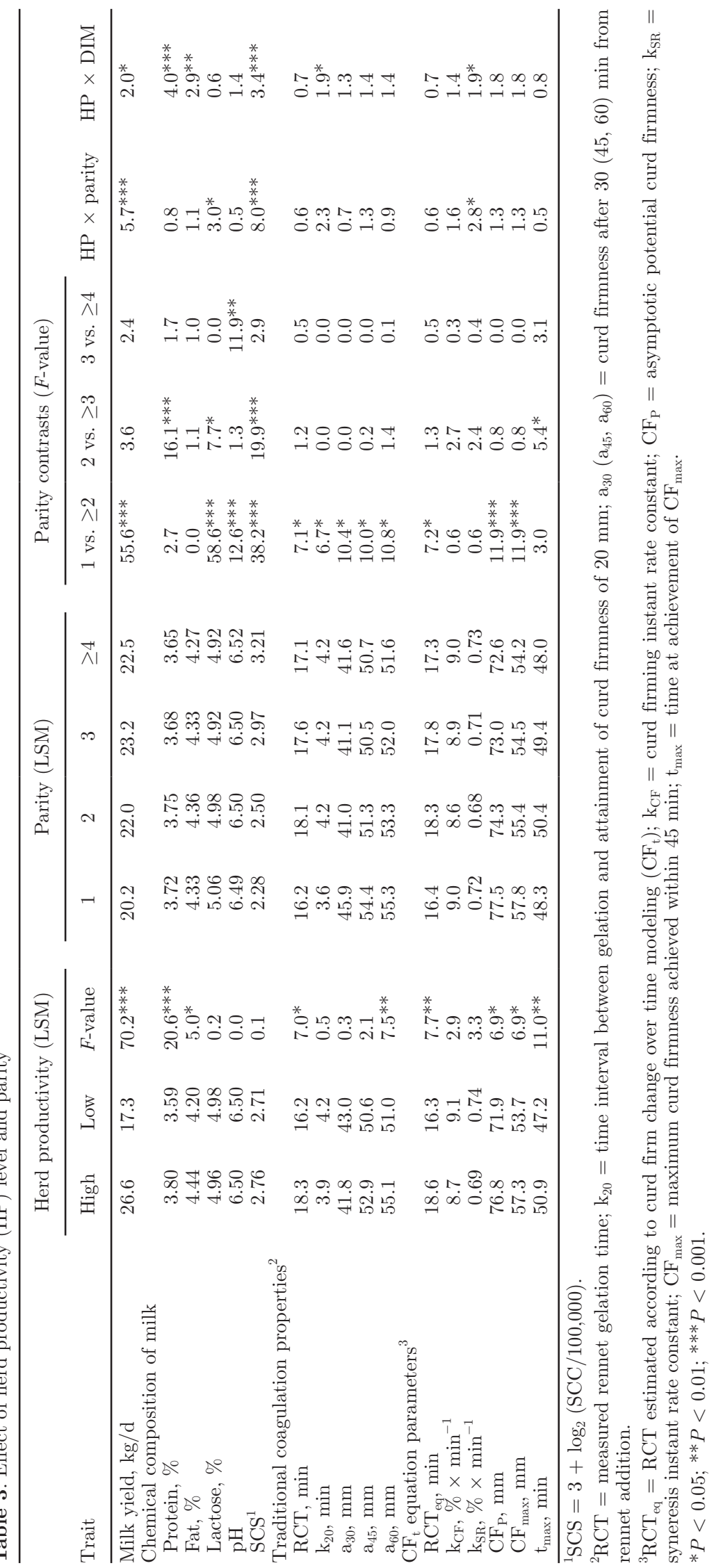


HP farms. Parity affected all traditional coagulation traits: milk samples from primiparous cows had faster coagulation and higher curd firming properties than milk from multiparous cows. The only significant, but not relevant, interaction was HP $\times$ DIM for $\mathrm{k}_{20}$.

Moving to the $\mathrm{CF}_{\mathrm{t}}$ model parameters and derived traits, predicted $\mathrm{RCT}_{\text {eq }}$ was very similar to the measured trait (shorter in samples from low-HP farms and from primiparous cows), although samples from low$\mathrm{HP}$ farms also had a smaller $\mathrm{CF}_{\mathrm{P}}$ and a smaller $\mathrm{CF}_{\max }$ attained at a shorter $t_{\max }$ time than the samples from high-HP farms.

Results confirmed that milk from primiparous cows coagulates faster than milk from multiparous cows $\left(\mathrm{RCT}_{\text {eq }}\right)$, and attained a greater $\mathrm{CF}\left(\mathrm{CF}_{\mathrm{P}}\right.$ and $\left.\mathrm{CF}_{\max }\right)$ but had similar curd-firming and syneresis instant rate constants $\left(\mathrm{k}_{\mathrm{CF}}\right.$ and $\left.\mathrm{k}_{\mathrm{SR}}\right)$ in the same $\mathrm{t}_{\max }$. Modest HP $\times$ parity and HP $\times$ DIM interactions were observed for $\mathrm{k}_{\mathrm{SR}}$.

\section{Effect of DIM}

The variation during lactation was highly significant for all the traits analyzed. In the case of daily MY, an interaction between DIM and HP was also noted. In fact, it can be seen from Figure 1 that cows reared in farms characterized by high HP displayed (as an average of the 6 breeds studied) the typical pattern observed in dairy cows: an increase in production until lactation peak (65 to 95 DIM class) and an almost linear decrease thereafter. The pattern of MY was different in cows reared on farms characterized by low HP, because the lactation peak coincided with the first DIM class ( 5 to $35 \mathrm{~d}$ ) followed by an almost linear decrease.

The average values of the fat and protein contents of milk were lowest in samples collected at 35 to 65 DIM (3.79 and $3.39 \%$, respectively), and then increased almost linearly until the end of lactation (4.78 and $4.08 \%$, respectively). The HP $\times$ DIM interaction also affected these traits (Table 3 ). The milk protein content of cows from high HP was +0.25 percentage points greater than from low HP at the beginning of lactation, and decreased progressively to +0.06 at the end (data not shown). Milk fat content exhibited a similar although more variable trend, moving from +0.38 to +0.13 percentage points during lactation in favor of the cows reared in high HP.

Lactose exhibited an opposite pattern to fat and protein, the highest value $(5.12 \%)$ being in the second DIM class and the lowest in the last $(4.86 \%)$. The $\mathrm{pH}$ increased over the first 3 classes of DIM (6.45 to 6.50), then to 6.52 at the end of lactation. Similarly to fat and protein, average SCS values were lowest in the second DIM class (2.15), and then progressively increased until

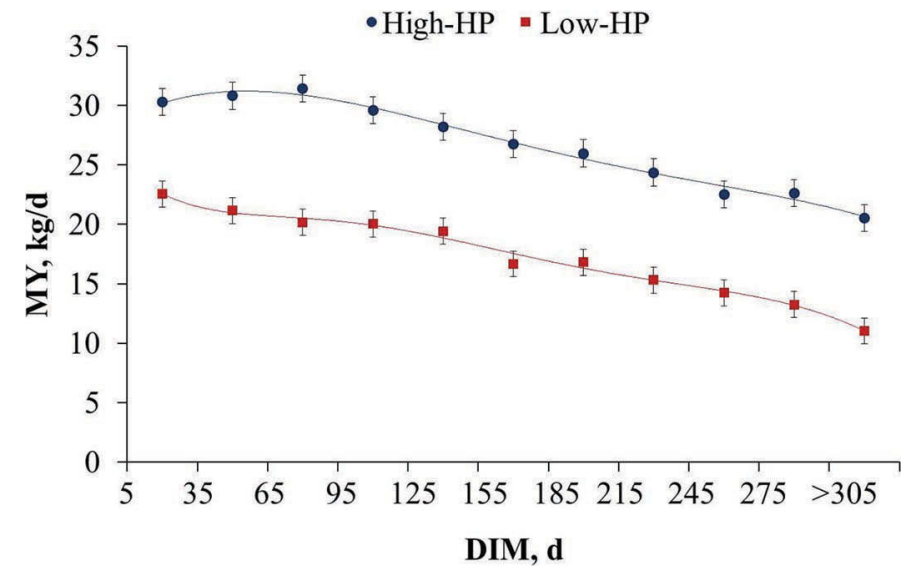

Figure 1. Effect of interaction $(P=0.03)$ between herd productivity level (high HP and low HP) expressed in milk yield (MY, $\mathrm{kg} / \mathrm{d}$ ) and stage of lactation (each point represents the LSM and standard error of the interaction HP $\times$ DIM from a model including herd within HP, 6 breed effect, parity, and its interactions with HP and breed). Color version available online.

the end of lactation (3.65). Although the HP $\times$ DIM interaction was significant (Table 3), comparison of the 2 HP levels did not exhibit a clear trend during lactation, the values being more erratic (data not shown).

The pattern of traditional single-point MCP during lactation is shown in Figure 2. It is evident that RCT increased rapidly during the first part of lactation, whereas the changes occurred more slowly during the second part. The $\mathrm{k}_{20}$ trait increased slightly during the first trimester of lactation, but the initial values tended to recover during the following two-thirds of lactation. All 3 curd firmness values $\left(a_{30}, a_{45}\right.$, and $\left.a_{60}\right)$ were high at the beginning of lactation, reduced during the first part of lactation, stable during mid lactation, and tended to increase in the last couple of months.

The patterns of the $\mathrm{CF}_{\mathrm{t}}$ modeling parameters and derived traits are shown in Figure 3 (the $\mathrm{RCT}_{\text {eq }}$ pattern is not shown because it was almost identical to the traditional RCT pattern reported in Figure 2a). The pattern of the traits showing asymptotical potential and maximum curd firmness $\left(\mathrm{CF}_{\mathrm{P}}\right.$ and $\left.\mathrm{CF}_{\max }\right)$ was similar to the pattern for traditional curd firmness: a decrease at the beginning, stabilization in the middle, and improvement toward the end of lactation. The pattern of the time needed to attain $\mathrm{CF}_{\max }\left(\mathrm{t}_{\max }\right)$ was opposite to that of $\mathrm{CF}_{\max }$. Of the 2 instant rate constants, $\mathrm{k}_{\mathrm{CF}}$ showed a slight decrease at the beginning of lactation followed by a rapid increasing until the end of lactation, whereas $\mathrm{k}_{\mathrm{SR}}$, in contrast, was the only trait not affected by stage of lactation. The effect on $\mathrm{CF}_{\mathrm{t}}$ modeling of different coagulation conditions (e.g., rennet concentration, $\mathrm{pH}, \mathrm{Ca}$, casein content), especially in late-lactation samples, needs to be further investigated. 

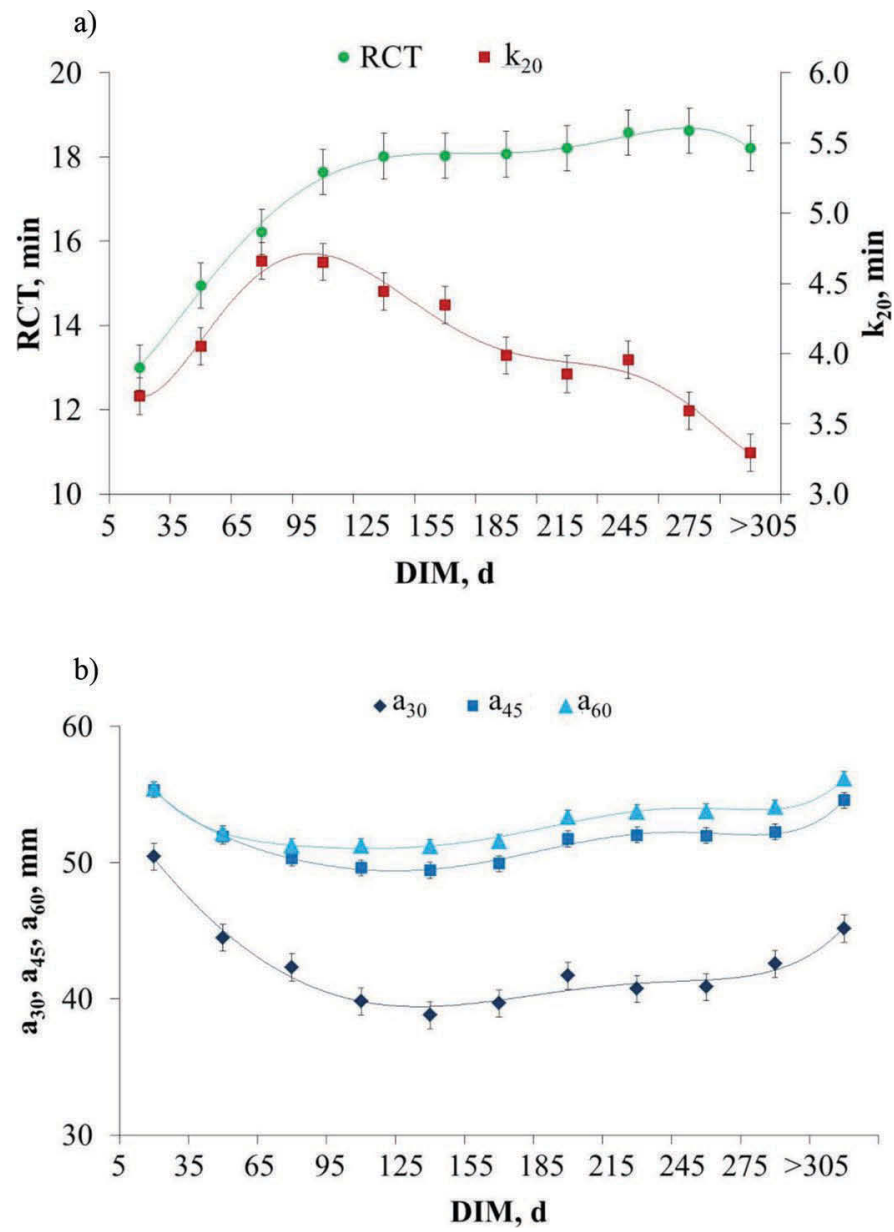

Figure 2. Effect of DIM on traditional milk coagulation properties: (a) rennet coagulation time $(\mathrm{RCT} ; P<0.0001)$ and time interval between gelation and attainment of curd firmness of $20 \mathrm{~mm}\left(\mathrm{k}_{20} ; P\right.$ $<0.0001)$ and (b) curd firmness at $30\left(\mathrm{a}_{30}, P<0.0001\right), 45\left(\mathrm{a}_{45}, P=\right.$ $0.002)$, and $60\left(\mathrm{a}_{60}, P<0.0001\right) \mathrm{min}$. Error bars represent SEM. Color version available online.

\section{Effect of Breed}

Least squares means of the effects of breed and their orthogonal contrasts ( $F$-value) for all the observed traits are reported in Table 4. All LSM values are corrected for all other factors of variation included in the model (herd productivity class, individual herds, and parity and DIM of the cows).

Comparing first the average of the 3 specialized dairy breeds (HF, BS, and Je) with those of the dual-purpose breeds ( $\mathrm{Si}$, Re, and AG), MY was not statistically different. Regarding milk quality traits, specialized dairy breeds out-yielded dual-purpose breeds in the 3 major components (protein, fat, and lactose) but not in average $\mathrm{pH}$ or SCS. The productive aptitude of cows did not in itself affect any traditional coagulation properties or any $\mathrm{CF}_{\mathrm{t}}$ parameters or derived traits, with the sole exception of the speed of the process as described by the 2 instant rate constants for curd firming and syneresis (faster, on average, with dairy breeds than with dual-purpose breeds).

The 3 specialized dairy breeds differed considerably from each other for almost all traits analyzed, whereas the differences were smaller among the 3 dual-purpose breeds. Results confirmed the small-framed dairy breed (Jersey) to have a smaller productive potential (daily milk yield: $-31 \%$ ) than the large-framed dairy breeds (Holstein Friesian and Brown Swiss), but higher milk protein $(+11 \%)$ and fat $(+35 \%)$ contents. Both the lactose content and $\mathrm{pH}$ of Jersey milk were slightly lower than in the heavier breeds. Milk from Jersey cows was characterized by much more favorable technological properties, whether expressed as $\mathrm{MCP}$ or $\mathrm{CF}_{\mathrm{t}}$ parameters and derived traits (Table 4).
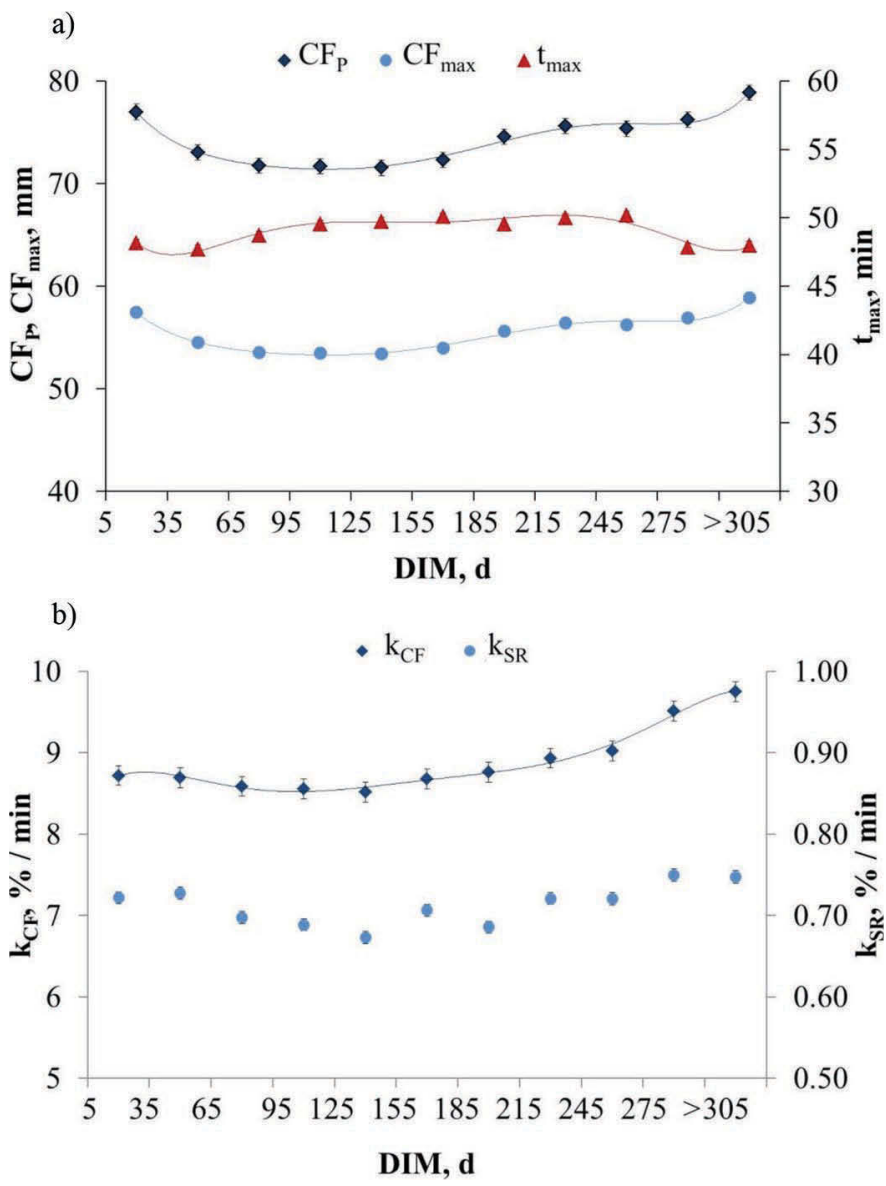

Figure 3. Effect of DIM on curd firmness time modeling parameters $\left(\mathrm{CF}_{\mathrm{t}}\right)$ and derived traits: (a) asymptotic potential curd firmness $\left(\mathrm{CF}_{\mathrm{P}} ; P<0.001\right)$, maximum curd firmness achieved within 45 $\min \left(\mathrm{CF}_{\max } ; P<0.001\right)$, time at achievement of $\mathrm{CF}_{\max }\left(\mathrm{t}_{\max } ; P<\right.$ $0.01)$, and (b) curd firming instant rate constant $\left(\mathrm{k}_{\mathrm{CF}} ; P<0.001\right)$ and $\mathrm{k}_{\mathrm{SR}}$ (syneresis instant rate constant; NS); rennet coagulation time (RCT) estimated according to curd firm change over time modeling $\left(\mathrm{CF}_{\mathrm{t}}\right)\left(\mathrm{RCT}_{\mathrm{eq}}\right)$ showed values very similar to those of RCT reported in Figure $2 \mathrm{a}$ and is not shown. Error bars represent SEM. Color version available online. 


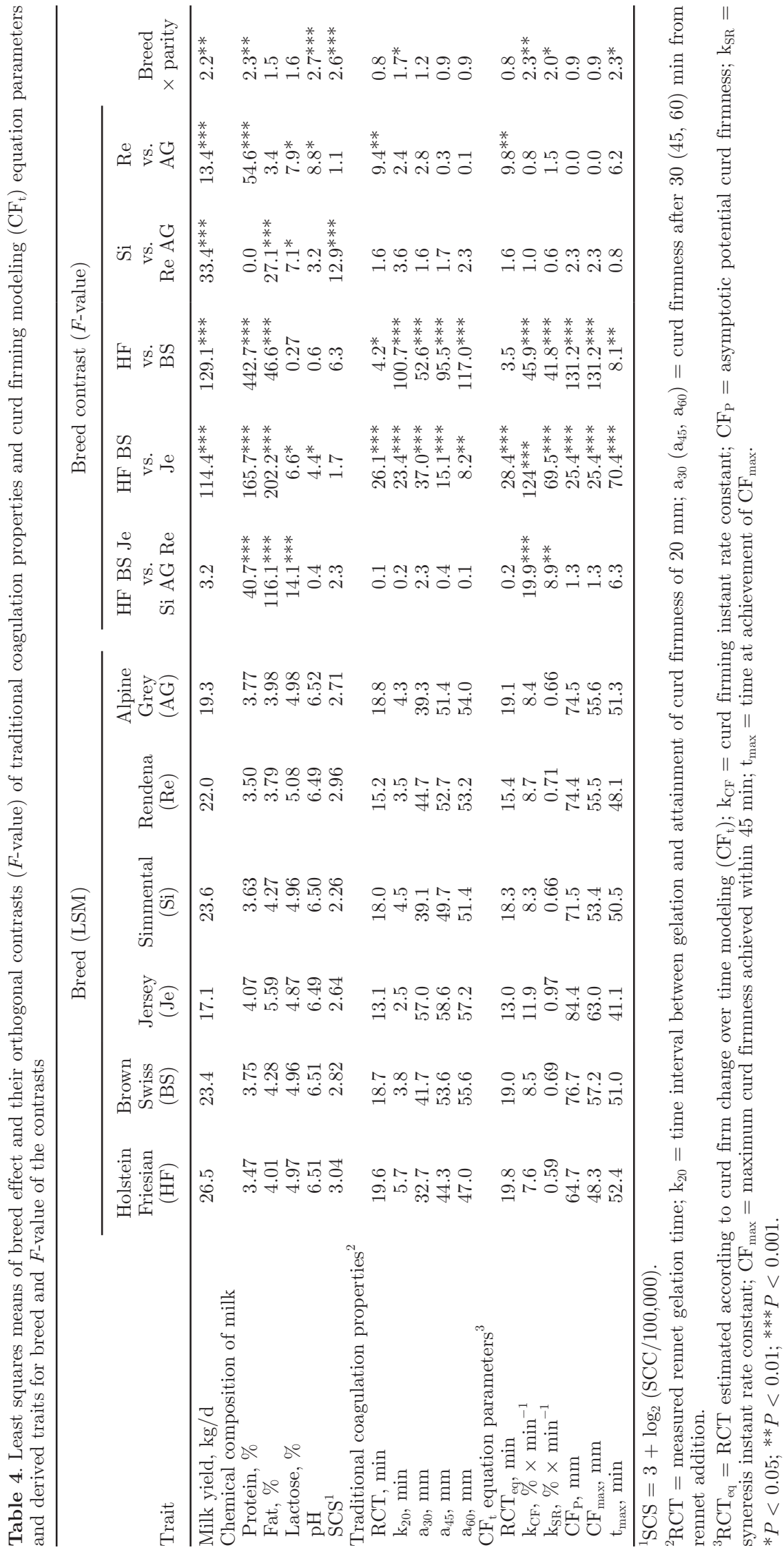


Compared with Holstein Friesians, Brown Swiss cows had a slightly lower productive potential $(-12 \%)$, compensated for by greater milk fat and protein contents $(+8 \%$ and $+7 \%$, respectively), and, in particular, by much more favorable milk technological properties.

Moving to dual-purpose breeds, the large-framed Simmental cows produced, on average, more milk $(+14 \%)$ than the cows of the 2 medium-framed local breeds (Rendena and Alpine Grey), with a greater fat content $(+10 \%)$ and a much lower SCC $(-20 \%$ SCS, corresponding to $-33 \%$ SCC). No differences were found between the averages of the 2 local breeds with respect to the coagulation, curd firming and syneresis properties of milk.

The differences recorded between the 2 local breeds were that Rendena cows produced more milk, with less protein, a lower $\mathrm{pH}$, more lactose, and higher SCS than Alpine Greys. Moreover, Rendena milk samples coagulated earlier than Alpine Grey milk samples. The breed $\times$ parity interaction affected MY, milk $\mathrm{pH}, \mathrm{SCS}$, and rate of curd firming traits $\left(\mathrm{k}_{20}, \mathrm{k}_{\mathrm{CF}}, \mathrm{k}_{\mathrm{SR}}\right.$, and $\left.\mathrm{t}_{\max }\right)$, but these differences were not quantitatively important.

\section{DISCUSSION}

\section{Modeling the Coagulation, Curd Firming, and Syneresis Process}

The major limitations of traditional MCP in cattle species, but not in sheep (Vacca et al., 2015), are the existence of NC samples (milk not coagulating within 30 min of rennet addition), from which it is impossible to estimate RCT, $\mathrm{k}_{20}$, and $\mathrm{a}_{30}$, as well as the high frequency of LC samples, in which it is difficult to obtain a $k_{20}$ value (not reaching $20 \mathrm{~mm}$ of curd firmness within $30 \mathrm{~min}$ ), and the high correlation between RCT and $\mathrm{a}_{30}$, especially in LC samples, so that the latter trait does not add much information (Bittante et al., 2013). The use of traditional MCP with a 30-min test duration could bias comparisons among breeds or dairy systems, characterized by different incidences of $\mathrm{NC}$ and LC samples. In addition, the traditional lactodynamograph setup for analyzing bovine milk was designed to explore primarily the coagulation and curd-firming process, not syneresis.

Therefore, extending the lactodynamographic analysis beyond $30 \mathrm{~min}$ and applying a 4-parameter curd firming model allowed us to model the entire pattern of coagulation, curd firming, and syneresis. The number of NC samples (without any traditional MCP measures) decreased from about $6.3 \%$ of milk samples at 30 min from rennet addition to less than $1.0 \%$ at 60 min. Also, the number of LC samples (those failing to reach a minimum curd firmness of $20 \mathrm{~mm}$; i.e., no $\mathrm{k}_{20}$ ) was $17.0 \%$ after $30 \mathrm{~min}$ and only $2.6 \%$ after $60 \mathrm{~min}$. However, it was also possible to extract the new parameters from the majority of these very-late-coagulating samples using the $\mathrm{CF}_{\mathrm{t}}$ equation, so that milk samples without predicted $\mathrm{CF}_{\mathrm{t}}$ parameters only accounted for $1.1 \%$ of the total. Moreover, the pattern of coagulation, curd firming, and syneresis emerged more clearly from the model based on all 240 informative points for each sample than from 5 of those points, as with traditional traits.

The repeatability obtained was similar to that estimated by other authors on relatively small sets of data, (Caroli et al., 1990; Dal Zotto et al., 2008). The only previous study estimating the repeatability of modeled parameters (Bittante et al., 2013) used a 4-parameter model based on data from bulk milk samples from Holstein Friesian cows of one experimental herd, and not from individual milk samples from cows of 6 breeds reared in 41 mixed-breed farms, as in the present study. Moreover, repeatability was not expressed in terms of the proportion of total variance but in the unit of measure of each trait. Comparison of the 2 trials could be carried out using the residual mean square error as an indication of between-replicate variability. Compared with the previous trial, in the present study the residual variability was larger for $\mathrm{RCT}_{\text {eq }}$ (1.6 vs. 0.7 min, respectively), similar for $\mathrm{CF}_{\mathrm{P}}$ (7.1 vs. $6.9 \mathrm{~mm}$, respectively) and $\mathrm{k}_{\mathrm{CF}}$ (1.5 vs. $1.8 \% / \mathrm{min}$, respectively), and smaller for $\mathrm{k}_{\mathrm{SR}}$ (0.17 vs. $0.33 \% / \mathrm{min}$, respectively). In any case, repeatability was satisfactory for $\mathrm{RCT}_{\text {eq }}$, $\mathrm{CF}_{\mathrm{P}}$, and $\mathrm{CF}_{\max }$, but lower for $\mathrm{k}_{\mathrm{CF}}, \mathrm{k}_{\mathrm{SR}}$, and $\mathrm{t}_{\max }$. It is clear that the increased interest in prolonging the duration of the test should motivate the instrument manufacturer to produce lactodynamographs with improved repeatability in the second part of the prolonged test.

\section{Effects of Animal and Herd on Lactodynamographic Traits}

Figure 4 shows the combined effects of parity on $\mathrm{CF}_{\mathrm{t}}$ modeling parameters and highlights the superiority of milk from primiparous over multiparous cows, confirming the results found with traditional MCP (Tyrisevä et al., 2003) as well as modeled $\mathrm{CF}_{\mathrm{t}}$ patterns (Malchiodi et al., 2014; Bittante et al., 2015).

In addition to the recognized effects of lactation stage on milk production and quality traits, the present study confirmed the importance of DIM for both traditional $\mathrm{MCP}$ and $\mathrm{CF}_{\mathrm{t}}$ equation parameters. Figure 5 clearly shows that the effect of DIM is more important for coagulation than for curd firming and syneresis traits, and that milk produced at the beginning of lactation is superior to that produced thereafter, confirming previous reports by Macheboeuf et al. (1993a), Kreuzer et al. 


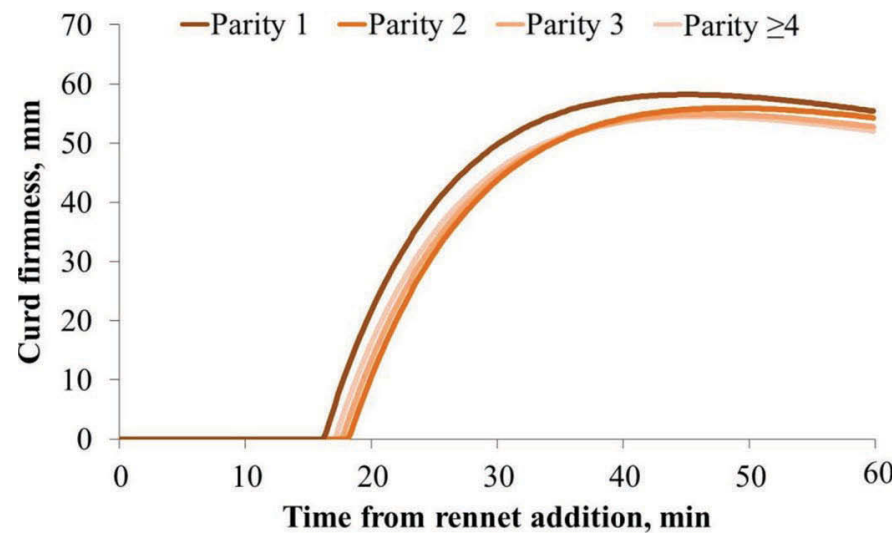

Figure 4. Pattern of curd firmness after rennet addition $\left(\mathrm{CF}_{\mathrm{t}}\right.$ modeling) of milk samples across classes of parity. Color version available online.

(1996), Tyrisevä et al. (2004), Jõudu et al. (2007), and Malchiodi et al. (2014).

Some studies carried out on a large number of cows with repeated samplings made it possible to estimate the animal repeatability of lactodynamographic traits after correcting for parity and DIM. As reviewed by Bittante et al. (2012), the animal repeatability of the main traditional MCP was close to $60 \%$, slightly greater than for MY and composition traits. The animal repeatability estimated by Caroli et al. (1990) for the same traits was slightly lower (48 to $56 \%$ ). In the present study, the animal repeatability of traditional MCP was greater, close to $80 \%$, but it was calculated on replicated analyses of the same milk sample, not on subsequent samplings.

No estimates relating to animal repeatability are available in the scientific literature for the new model-

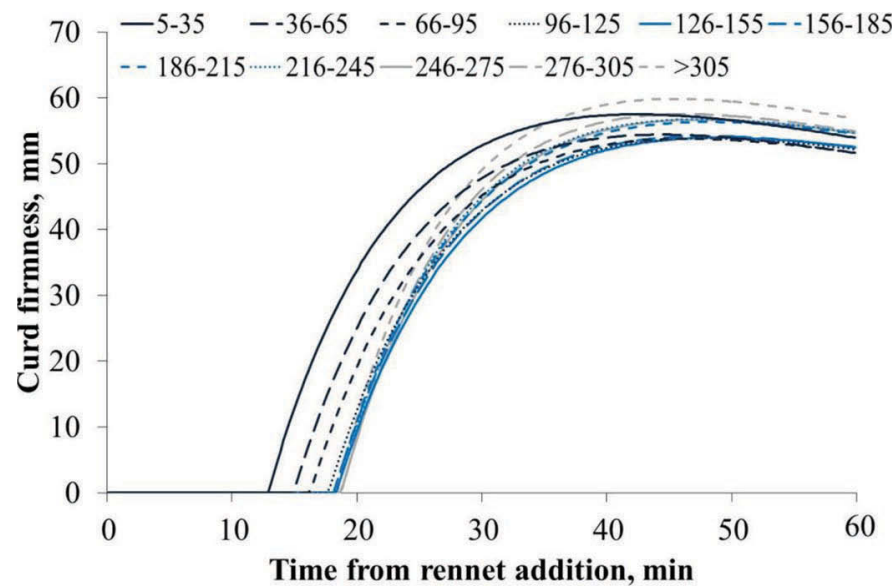

Figure 5. Pattern of curd firming after rennet addition $\left(\mathrm{CF}_{\mathrm{t}}\right.$ modeling) of milk samples according to stage of lactation (DIM). Color version available online. ing parameters and derived traits. Regarding the lower instrumental repeatability with the increased time interval from rennet addition, animal repeatability was $82 \%$ for $\mathrm{RCT}_{\text {eq }}$, around $60 \%$ for the 2 instant rate constants, and much lower for the remaining traits (as for single-point $\mathrm{a}_{60}$ ).

The effect of individual herd has also been studied in several large surveys, although only a few of them included individual herd as a random factor allowing an estimation to be made of the corresponding variance component expressed as a proportion of total variance. Tyrisevä et al. (2004), Ikonen et al. (2004), and Vallas et al. (2010) sampled a large number of farms (73 to 693) and included this effect as a random effect in modeling MCP data. Herd variability in these studies represented a small proportion (lower than $10 \%$ ) of total variance of traditional MCP. Slightly greater was the incidence of herd variance on total variance obtained by Cecchinato et al. (2013) on traditional MCP obtained from prolonged tests using different techniques.

The present study confirmed that the effect of herddate within class of herd productivity represented a very low proportion (6 to $13 \%$ ) of total variability for both traditional single-point $\mathrm{MCP}$ and new $\mathrm{CF}_{\mathrm{t}}$ modeling parameters and derived traits, especially when compared with MY and milk quality traits (Table 2). If we consider that herd clusters several management criteria, such as housing conditions (freestalls vs. tiestalls), diet administration (e.g., TMR, silage, summer pastures) and diet quality (percentage of starch, NDF, and $\mathrm{CP}$ ), and that herd here is combined with date of sample collection (and therefore also with season), the percentage variability in MCP and the modeled parameters explained by this factor is very low. This means that improvement in the $\mathrm{MCP}$ and $\mathrm{CF}_{\mathrm{t}}$ parameters is affected mainly by variation in individual animal factors (e.g., breed, genetics, parity, stage of lactation) and much less by factors such as environment, farm management, animal feeding, milking systems, and so on.

\section{Effect of Herd Productivity on Lactodynamographic Properties}

To our knowledge, no previous studies have investigated the effect of herd productivity (high or low) on the lactodynamographic properties of milk. Only Oloffs et al. (1992) sampled animals on about 1,400 farms and separated them into 3 classes based on average milk production levels, but the effect of these classes of herd productivity on the response variables was not shown. However, milk energy output (dMEO, MJ/d) is based on daily production of fat, protein, and lactose, and this explains why, after correcting for breed, 
DIM, and parity of cows, the herds with high HP not only had higher daily MY but also better milk quality. Moreover, the herds with the highest average milk energy outputs are probably the best managed (i.e., in terms of diet and health). On the other hand, milk coagulation ( $\mathrm{RCT}$ and $\mathrm{RCT}_{\text {eq }}$ ) was faster in samples from herds characterized by low HP, but curd firmness tended to be reduced (Table 2). The combined effect of HP on lactodynamographic traits can be seen in Figure 6 , which shows the patterns of coagulation, curd firming, and syneresis obtained from the LSM of the $\mathrm{CF}_{t}$ equation parameters for the $2 \mathrm{HP}$ classes. It is evident that in the first phase of the test (until $30 \mathrm{~min}$ ), milk samples from low HP farms were better, whereas the opposite is true in the second phase of the test (not analyzed in a traditional 30-min test). It worth noting that the parameters relative to the second phase of the lactodynamographic test are those better correlated with cheese yield and fat and protein recovery in the curd (Cecchinato and Bittante, 2016).

Further information can be obtained indirectly from the survey carried out by Tyrisevä et al. (2004), which classified 125 Finnish dairy farms not according to production level but to some of the cows' feeding criteria (number of daily administrations of concentrates and type of concentrate used). The RCT was not affected by feeding criteria, but a small favorable effect on $\mathrm{a}_{30}$ was observed, including a moderate amount of oats in the diet. In particular, feeding practices leading to greater milk yield (use of compound feed and concentrates administrated 4 or more times per day) led to an improvement in MCP similar to that found in the present study's comparison of milk from farms characterized by high and low average dMEO (Table 3). Recently, in a survey carried out on 85 herds of Brown Swiss cows, we found that traditional farms with lower average milk yields produced milk characterized by earlier coagulation, a greater syneresis rate, and a smaller and earlier $\mathrm{CF}_{\max }$ than milk from modern, more productive farms (Bittante et al., 2015), a result similar to our comparison of low and high HP.

Several experimental studies on the effects of feeding strategy on MCP have been published (Malossini et al., 1996; Coulon et al., 2004), but they often compared different forages, concentrates or supplements, and found small differences in the average milk yield of cows.

The relationships between the productivity of individual cows within herd and lactodynamographic traits have been the subject of several studies. In a review of 8 studies on phenotypic and genetic parameters at the population level, Bittante et al. (2012) found very low phenotypic correlations between individual milk yield and traditional MCP $(-0.06 \pm 0.08$ for $\mathrm{RCT}$ and -0.03 \pm 0.04 for $\mathrm{a}_{30}$ ), and more variable genetic correlations

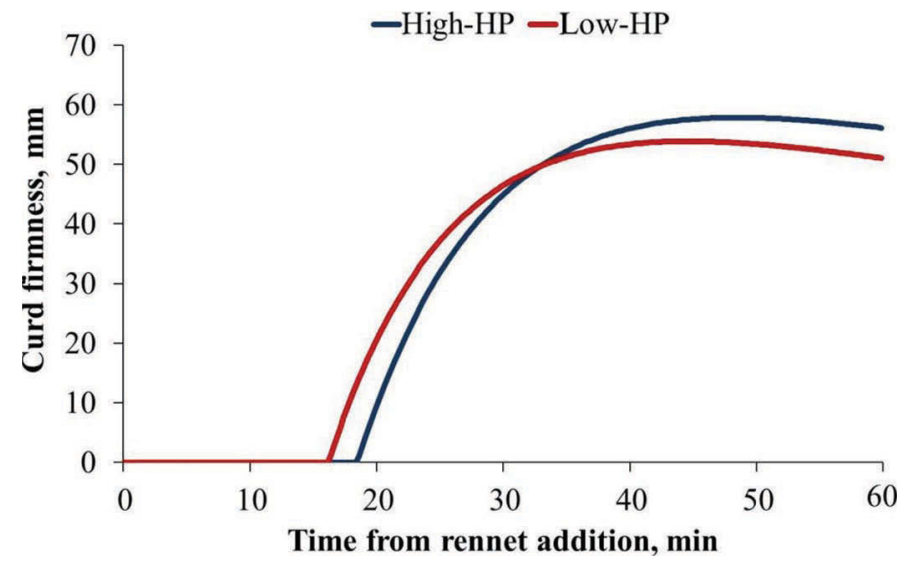

Figure 6. Pattern of curd firming after rennet addition $\left(\mathrm{CF}_{\mathrm{t}}\right.$ modeling) of milk samples according to herd productivity level (high HP or low HP) defined by the herd's average daily milk energy output of the cows (corrected for breed, parity, and DIM). Color version available online.

$\left(-0.15 \pm 0.18\right.$ for RCT and $+0.04 \pm 0.22$ for $\left.\mathrm{a}_{30}\right)$. Herd productivity seems to have a greater effect than individual cow productivity within herd on both traditional and modeled MCP.

\section{Effect of Breed Within Herd}

In the present study, large differences among breeds were found. The comparisons of different cattle breeds in published research are almost all based on traditional MCP obtained from lactodynamographic tests of $30 \mathrm{~min}$. In these conditions, an appreciable number of milk samples do not coagulate (NC samples) and do not yield any MCP measures. As the incidence of NC samples differs in different breeds and these samples cannot yield any MCP traits, they can bias the estimation of MCP among different breeds, as discussed by Bittante et al. (2012), if the statistical models do not accommodate censoring (Cecchinato and Carnier, 2011). The bias on the $\mathrm{k}_{20}$ trait is even larger due to the LC samples, whose late coagulation does not allow curd firmness to reach the value of $20 \mathrm{~mm}$ (no $\mathrm{k}_{20}$ value). The entity of the bias in traditional MCP traits when comparing different breeds (in particular, Holstein Friesian with Jersey and Rendena) could be predicted from the large differences across breeds in the incidence of $\mathrm{NC}$ and LC samples $30 \mathrm{~min}$ after rennet addition, as shown in Figure 7. Extending the test duration to 60 min greatly reduced the incidence of both $\mathrm{NC}$ and $\mathrm{LC}$ samples, so that the results reported in Table 4 for traditional MCP could be considered almost unbiased. The situation is even better for $\mathrm{CF}_{\mathrm{t}}$ traits, as the incidence of samples without trait prediction is about $1 \%$. 
(a)

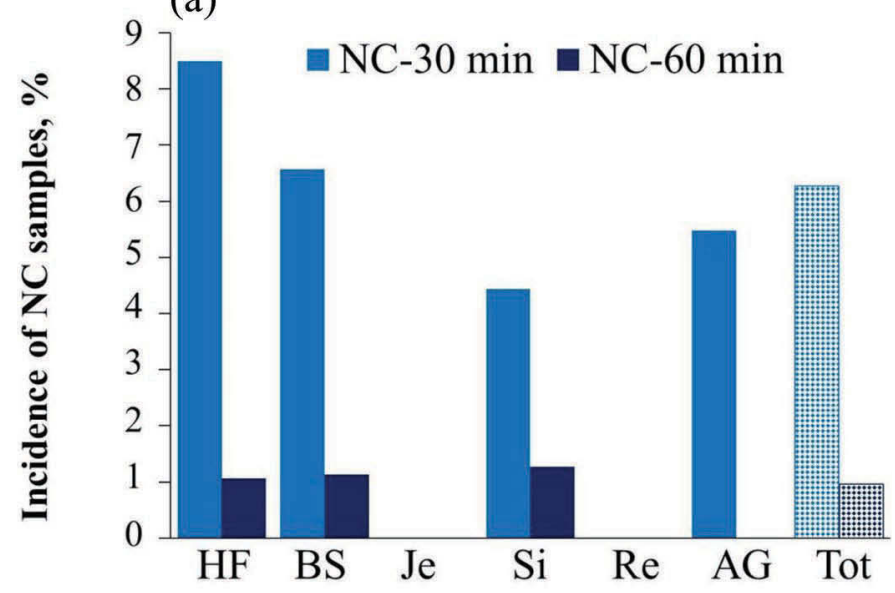

(b)

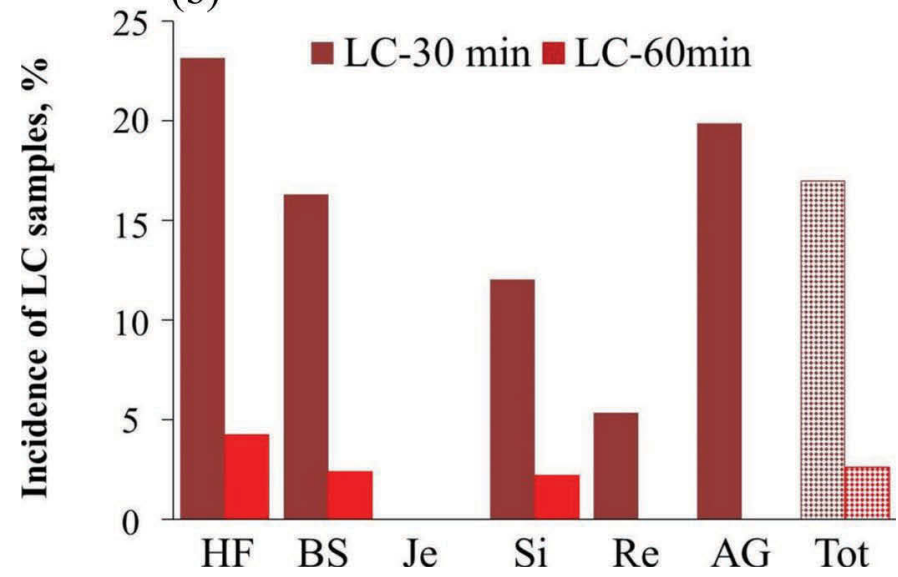

Figure 7. Incidence of (a) noncoagulating (NC) and (b) late-coagulating (LC) milk samples in different cattle breeds after 30 or $60 \mathrm{~min}$ from rennet addition. $\mathrm{HF}=$ Holstein-Friesian; $\mathrm{BS}=$ Brown Swiss; Je $=$ Jersey; $\mathrm{Si}=$ Simmental; $\mathrm{Re}=$ Rendena; $\mathrm{AG}=$ Alpine Grey; Tot $=$ total. Color version available online.

The specialized dairy breeds, in particular, exhibited large differences. Compared with large-framed HolsteinFriesian and Brown Swiss cows, small-framed Jersey cows are well known for their very low average MY but also the very high content of both fat and protein. Jersey cows also had the best renneting properties of all the 6 breeds compared in the present study. This superiority confirms previous results from the studies comparing breeds reviewed by Bittante et al. (2012) and from a comparison of Jersey cows with Holstein and Swedish Red cows reared in different farms by Poulsen et al. (2013).

Of the 2 large-framed dairy breeds ( $\mathrm{HF}$ and $\mathrm{BS}$ ), BS cows yielded very favorable MCP and produced milk with shorter RCT and $\mathrm{k}_{20}$ values and higher curd firmness than milk from HF (Table 4). These results agree with 9 studies reviewed by Bittante et al. (2012).
Within dual-purpose breeds, a large number of studies have confirmed the good average technological aptitude of milk from the large-framed Simmental breed, which was better than Holstein Friesian and close to Brown Swiss. These studies, like those on specialized dairy breeds, were mainly experimental trials carried out on research farms or, in some cases, surveys at the population level comparing milk from single-breed farms.

Medium-framed local breeds are of environmental significance, and are important from a cultural point of view, because they are related to local traditions and regional food products. Few studies have focused on measured MCP of local breeds, such as Alpine Grey and Rendena; however, De Marchi et al. (2007) in their survey, compared 5 of the 6 breeds investigated in our research, including the 2 local breeds (but no Jerseys). The analyses were carried out on samples of bulk milk from single-breed herds and the statistical model also included the effects of protein and fat percentages, SCS, titratable acidity, and log bacterial count, so that the effects of these 5 dairy cattle breeds reported also included the effects of differences in geographical area, dairy system and feeding, and management practice, but were corrected for milk quality traits. Nevertheless, the ranking of the 5 breeds was about the same as in the present study.

Because the differences among breeds were substantial, to distinguish the direct effect of breed on the lactodynamographic traits from the indirect effects arising from differences in milk composition and production, we included MY, protein, fat, lactose, $\mathrm{pH}$, and SCS as general covariates in the basic model. Then, we calculated the differences in breed variances between the 2 models, with and without covariates, for each lactodynamographic trait. The results (not shown) revealed that no traits were affected by MY, favorable effects were exerted by protein (especially on CF traits), fat (especially on milk coagulation time), and lactose (on all traits) contents, an increase in $\mathrm{pH}$ was unfavorably related to lactodynamographic traits, and SCS had a minor negative effect. These effects confirmed the majority of results reported in the scientific literature (Bittante et al., 2012). The effect of breed was not totally explained by the introduction of milk quality covariates into the model, because they remained highly significant for all the traits examined. However, the proportion of total breed variance explained by MY and quality traits was very different among traits: $20 \%$ or less for RCT traits and $t_{\max }$, and about 40 to $60 \%$ for the remaining traits (Figure 8). Even though the differences among the LSM of the 6 breeds were smaller after taking the effect of MY and quality traits into account, the ranking of the 6 breeds remained almost unchanged. 


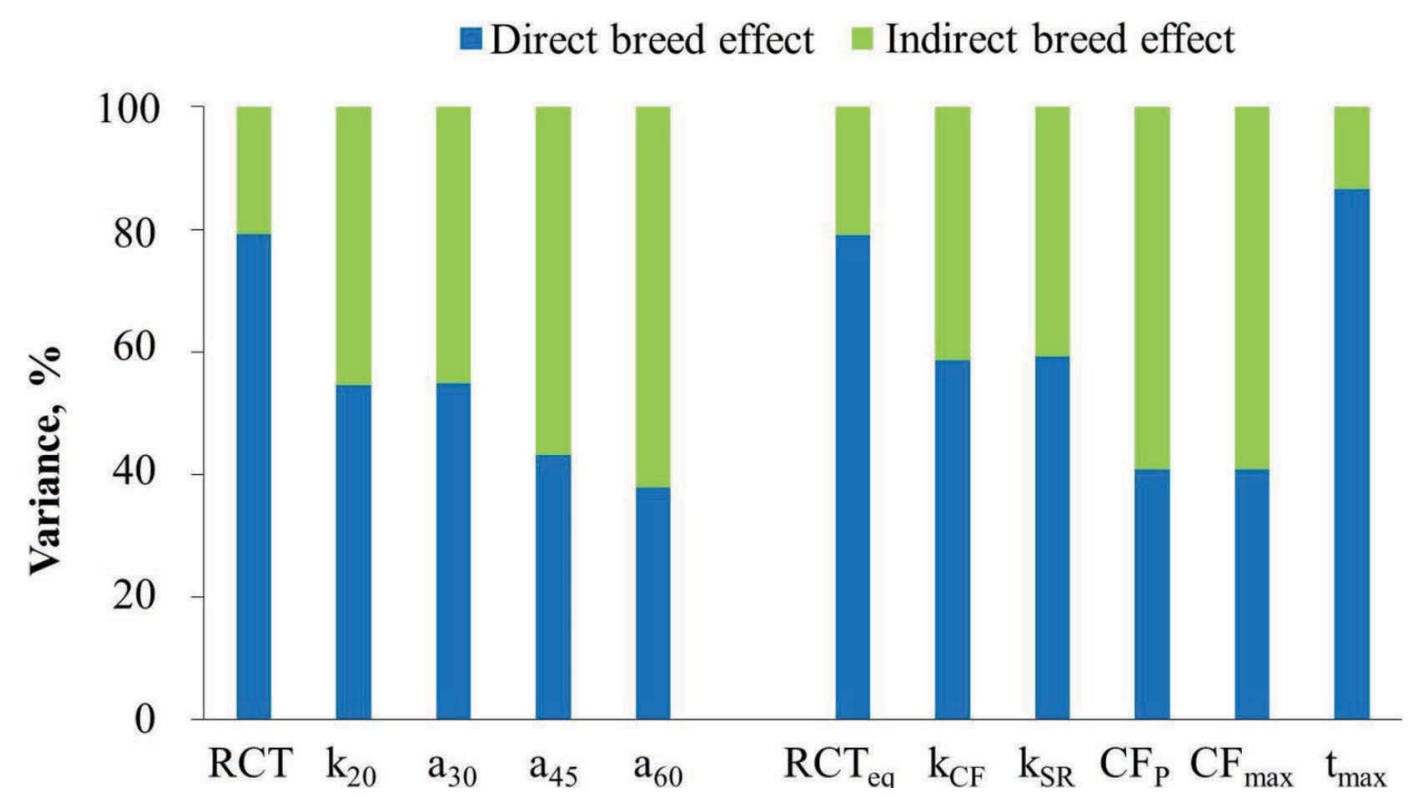

Figure 8. Proportion of total breed variance explained by direct or indirect breed effect through differences in milk yield and quality traits on milk coagulation properties and curd firmness modeling parameters $\left(\mathrm{CF}_{\mathrm{t}}\right)$ equation traits. $\mathrm{RCT}=$ measured rennet gelation time; $\mathrm{k}_{20}=$ time interval between gelation and attainment of curd firmness of $20 \mathrm{~mm} ; \mathrm{a}_{30}\left(\mathrm{a}_{45}, \mathrm{a}_{60}\right)=$ curd firmness after 30 (45, 60) min from rennet addition; $\mathrm{RCT}_{\mathrm{eq}}=\mathrm{RCT}$ estimated according to curd firm change over time modeling $\left(\mathrm{CF}_{\mathrm{t}}\right) ; \mathrm{k}_{\mathrm{CF}}=$ curd firming instant rate constant; $\mathrm{CF}_{\mathrm{P}}=$ asymptotic potential curd firmness; $\mathrm{k}_{\mathrm{SR}}=$ syneresis instant rate constant; $\mathrm{CF}_{\max }=$ maximum curd firmness achieved within 45 min; $\mathrm{t}_{\max }=$ time at achievement of $\mathrm{CF}_{\max }$. Color version available online.

No information is available in the scientific literature regarding the effect of breed of cows on the new $\mathrm{CF}_{t}$ model parameters. The only indirect information comes from a comparison of the patterns of coagulation and curd firming in milk from purebred Holstein Friesian cows with those of second- and third-generation crossbred cows (Malchiodi et al., 2014), which revealed a favorable effect of using Brown Swiss and Montbéliarde sires in the crossbreeding scheme.

The combined effects of breed on different lactodynamographic traits can be seen in Figure 9, which shows a comparison of the patterns of coagulation, curd firming, and syneresis obtained from the LSM of $\mathrm{CF}_{\mathrm{t}}$ equation parameters for the 6 breeds. It is evident that breed exerts a strong effect, much greater than the effects of parity (Figure 4), DIM (Figure 5), or herd productivity class (Figure 6). Also immediately evident is the superiority of the patterns characterizing the Jerseys and, in part, the Rendena breeds over the inferior Holstein-Friesian breed, whereas the other breeds of Alpine origin (Brown Swiss, Simmental, and Grey Alpine) were intermediate. The differences among breeds are slightly less evident after correcting all the MCP traits for milk yield and quality (data not shown), but the ranking of breeds remains about the same. Thus, the differences among breeds arise mainly from different genetic factors from those controlling milk, fat, protein, and lactose secretions.
As reviewed by Bittante et al. (2012), within breed, traditional MCP have been found to exhibit heritability coefficients similar to those characterizing other milk traits and significant effects of milk protein genetic variants (in particular, those related to $\kappa$-casein). But it has been shown that the effect of milk protein genetic variants can also explain, but only partially, the differences in the lactodynamographic profiles of different breeds (Ikonen et al., 1999; Auldist et al., 2002).

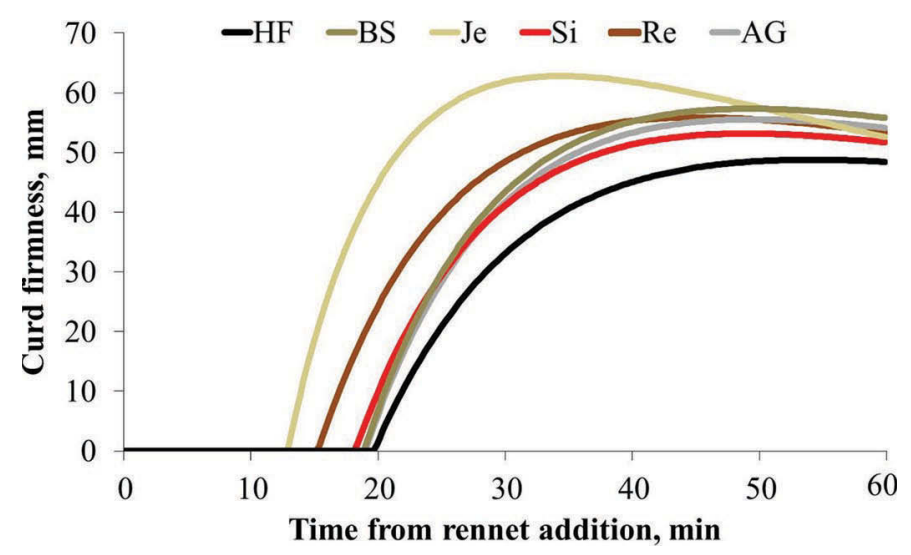

Figure 9. Pattern of curd firmness after rennet addition $\left(\mathrm{CF}_{\mathrm{t}}\right.$ modeling) of milk samples for the 6 breeds compared within herds. $\mathrm{HF}=$ Holstein-Friesian; BS = Brown Swiss; Je = Jersey; Si = Simmental; Re $=$ Rendena; $\mathrm{AG}=$ Alpine Grey. Color version available online. 
Candidate gene (Tyrisevä et al., 2008; Glantz et al., 2011; Cecchinato et al., 2012, 2015b) and genome-wide (Glantz et al., 2012; Gregersen et al., 2015; Dadousis et al., 2016) approaches have recently revealed that many other genes are involved in the control of these traits within breed, whether expressed as traditional MCP or $\mathrm{CF}_{\mathrm{t}}$ modeling. A comparison of different breeds with respect to the cheesemaking ability of their milk based on molecular information is still wanting, and could provide new insights into the reasons for the differences in breed not mediated by milk yield and composition.

In any case, prediction of traditional MCP at the population level by Fourier-transform infrared spectroscopy, and its use in indirect selection for cheesemaking aptitude has proven to be effective (Cecchinato et al., 2009; Ferragina et al., 2015), while there is still little information on modeled $\mathrm{CF}_{\mathrm{t}}$ traits.

\section{CONCLUSIONS}

This study on multi-breed herds allowed the effects of farm and of breed of cow to be independently evaluated. The use of $\mathrm{CF}_{\mathrm{t}}$ modeling based on all the information available after rennet addition and on extension of curd firmness recording allowed for better representation of the effects of the different factors examined on coagulation, curd firming, and syneresis. In particular, there was a relatively low incidence of the effect of herd and season on the coagulative ability of milk. Comparison of farms with high or low average daily milk energy output revealed some contradictory effects on coagulation and curd firmness. The factors differentiating herds (e.g., environment, facilities, feeding, management, health) may not be very important for traditional or modeled MCP traits, and improvements in these traits at the herd level should be based mainly on modifying individual cow factors. Breed remained the predominant effect, showing strong differences between specialized and dual-purpose breeds, and especially within the 2 groups, even after correcting for milk yield and quality. In particular, results confirmed the very good milk quality and coagulative aptitude of Jersey cows, and, in part, the dual-purpose Rendena cows, against the inferiority of Holstein-Friesian cows and the intermediate results of other breeds of Alpine origin. Moreover, after correcting for effects of parity and DIM, there was still a very high animal effect within breed, supporting that these traits have a strong genetic basis and raising the possibility of genetic improvement. Further research is needed to investigate genetic differences among and within breeds among individuals at the level of some candidate genes (especially milk protein genetic variants) and of a genome-wide approach. It is also important to study the effects of herd productivity and breed directly on cheese yield and milk nutrient recovery in cheese, which would pave the way for studies on the relationships between direct cheesemaking traits and $\mathrm{MCP}$ and $\mathrm{CF}_{\mathrm{t}}$ model parameters.

\section{ACKNOWLEDGMENTS}

The authors thank the Autonomous Province of Trento (Italy) for funding.

\section{REFERENCES}

Ali, A. K. A., and G. E. Shook. 1980. An optimum transformation for somatic cell concentration in milk. J. Dairy Sci. 63:487-490.

Andersen, B. B., A. De Baerdemaeker, G. Bittante, B. Bonaiti, J. J. Colleau, E. Fimland, J. Jansen, W. H. E. Lewis, R. D. Politiek, G. Seeland, T. J. Teehan, and F. Werkmeister. 1981. Performance testing of bulls in AI: Report of a working group of the commission on cattle production. Livest. Prod. Sci. 8:101-119.

Auldist, M. J., C. Mullins, B. O'Brien, B. T. O'Kennedy, and T. Guinee. 2002. Effect of cow breed on milk coagulation properties. Milchwissenschaft 57:140-143.

Bertoni, G., L. Calamari, M. G. Maianti, and B. Battistotti. 2005 Milk for Protected Denomination of Origin (PDO) cheeses: I. The main required features. Pages 217-228 in Indicators of Milk and Beef Quality. J. F. Hocquette and S. Gigli, ed. EAAP Publication 112. Wageningen Academic Publishers, Wageningen, the Netherlands.

Bittante, G. 2011. Modeling rennet coagulation time and curd firmness of milk. J. Dairy Sci. 94:5821-5832.

Bittante, G., A. Cecchinato, N. Cologna, M. Penasa, F. Tiezzi, and M. De Marchi. 2011. Factors affecting the incidence of first-quality wheels of Trentingrana cheese. J. Dairy Sci. 94:3700-3707.

Bittante, G., C. Cipolat-Gotet, F. Malchiodi, E. Sturaro, F. Tagliapietra, S. Schiavon, and A. Cecchinato. 2015. Effect of dairy farming system, herd, season, parity, and days in milk on modeling of the coagulation, curd firming, and syneresis of bovine milk. J. Dairy Sci. 98:2759-2774.

Bittante, G., B. Contiero, and A. Cecchinato. 2013. Prolonged observation and modelling of milk coagulation, curd firming, and syneresis. Int. Dairy J. 29:115-123.

Bittante, G., M. Penasa, and A. Cecchinato. 2012. Invited review: Genetics and modeling of milk coagulation properties. J. Dairy Sci. 95:6843-6870.

Caroli, A., P. Bolla, G. Pagnacco, M. Rampilli, and L. Degano. 1990. Repeatability of milk clotting aptitude evaluated by lactodynamographic analysis. J. Dairy Res. 57:141-142.

Cecchinato, A., A. Albera, C. Cipolat-Gotet, A. Ferragina, and G. Bittante. 2015a. Genetic parameters of cheese yield and curd nutrient recovery or whey loss traits predicted using Fourier-transform infrared spectroscopy of samples collected during milk recording on Holstein, Brown Swiss and Simmental dairy cows. J. Dairy Sci. 98:4914-4927.

Cecchinato, A., and G. Bittante. 2016. Genetic and environmental relationships of different measures of individual cheese yield and curd nutrients recovery with coagulation properties of bovine milk. J. Dairy Sci. 99:1975-1989.

Cecchinato, A., and P. Carnier. 2011. Short communication: Statistical models for the analysis of coagulation traits using coagulating and non-coagulating milk information. J. Dairy Sci. 94:4214-4219.

Cecchinato, A., S. Chessa, C. Ribeca, C. Cipolat-Gotet, T. Bobbo, J. Casellas, and G. Bittante. 2015b. Genetic variation and effects of candidate-gene polymorphisms on coagulation properties, curd firmness modeling and acidity in milk from Brown Swiss cows. Animal 9:1104-1112

Cecchinato, A., C. Cipolat-Gotet, J. Casellas, M. Penasa, A. Rossoni, and G. Bittante. 2013. Genetic analysis of rennet coagulation time, curd-firming rate, and curd firmness assessed over an extended 
testing period using mechanical and near-infrared instruments. J. Dairy Sci. 96:50-62.

Cecchinato, A., M. De Marchi, L. Gallo, G. Bittante, and P. Carnier. 2009. Mid-infrared spectroscopy predictions as indicator traits in breeding programs for enhanced coagulation properties of milk. J. Dairy Sci. 92:5304-5313.

Cecchinato, A., C. Ribeca, A. Maurmayr, M. Penasa, M. De Marchi, N. P. P. Macciotta, M. Mele, P. Secchiari, G. Pagnacco, and G. Bittante. 2012. Short communication: Effects of $\beta$-lactoglobulin, stearoyl-coenzyme A desaturase 1, and sterol regulatory element binding protein gene allelic variants on milk production, composition, acidity, and coagulation properties of Brown Swiss cows. J. Dairy Sci. 95:450-454.

Coulon, J.-B., A. Delacroix-Buchet, B. Martin, and A. Pirisi. 2004. Relationships between ruminant management and sensory characteristics of cheeses: A review. Lait 84:221-241.

Dadousis, C., S. Biffani, C. Cipolat-Gotet, E. L. Nicolazzi, A. Rossoni, E. Santus, G. Bittante, and A. Cecchinato. 2016. Genome-wide association of coagulation properties, curd firmness modeling, protein percentage, and acidity in milk from Brown Swiss cows. J. Dairy Sci. 99:3654-3666.

Dal Zotto, R., M. De Marchi, A. Cecchinato, M. Penasa, M. Cassandro, P. Carnier, L. Gallo, and G. Bittante. 2008. Reproducibility and repeatability of measures of milk coagulation properties and predictive ability of mid-infrared reflectance spectroscopy. J. Dairy Sci. 91:4103-4112.

De Marchi, M., R. Dal Zotto, M. Cassandro, and G. Bittante. 2007. Milk coagulation ability of five dairy cattle breeds. J. Dairy Sci. 90:3986-3992.

Ferragina, A., G. de los Campos, A. I. Vazquez, A. Cecchinato, and G. Bittante. 2015. Bayesian regression models outperform partial least squares methods for predicting milk components and technological properties using infrared spectral data. J. Dairy Sci. 98:8133-8151.

Glantz, M., H. Lindmark Månsson, M. Paulsson, and H. Stålhammar. 2012. Genomic selection in relation to bovine milk composition and processability. J. Dairy Res. 79:53-59.

Glantz, M., H. Lindmark Månsson, H. Stålhammar, and M. Paulsson. 2011. Effect of polymorphisms in the leptin, leptin receptor, and acyl-coenzyme A:diacylglycerol acyltransferase 1 (DGAT1) genes and genetic polymorphism of milk proteins on cheese characteristics. J. Dairy Sci. 94:3295-3304.

Gregersen, V. R., F. Gustavsson, M. Glantz, O. F. Christensen, H. Stålhammar, A. Andrén, H. Lindmark-Månsson, N. A. Poulsen, L. B. Larsen, and M. Paulsson. 2015. Bovine chromosomal regions affecting rheological traits in rennet-induced skim milk gels. J. Dairy Sci. 98:1261-1272.

Horne, D. S., and J. M. Banks. 2004. Rennet-induced coagulation of milk. Pages 47-70 in Cheese Chemistry, Physics and Microbiology. Vol. 1. 3rd ed. Elsevier Applied Science, Amsterdam, the Netherlands.

Ikonen, T., K. Ahlfors, R. Kempe, M. Ojala, and O. Ruottinen. 1999. Genetic parameters for the milk coagulation properties and prevalence of noncoagulating milk in Finnish dairy cows. J. Dairy Sci. 82:205-214.

Ikonen, T., S. Morri, A.-M. Tyrisevä, O. Ruottinen, and M. Ojala. 2004. Genetic and phenotypic correlations between milk coagulation properties, milk production traits, somatic cell count, casein content, and pH of milk. J. Dairy Sci. 87:458-467.

ISO-IDF (International Organization for Standardization and International Dairy Federation). 2010a. Milk-Determination of fat content. International Standard ISO 1211 and IDF 1:2010. ISO, Geneva, Switzerland, and IDF, Brussels, Belgium.

ISO-IDF (International Organization for Standardization and International Dairy Federation). 2010b. Milk-Determination of lactose content-Enzymatic method using difference in $\mathrm{pH}$. International Standard ISO 26462:2010 and IDF 214:2010. ISO, Geneva, Switzerland, and IDF, Brussels, Belgium.
ISO-IDF (International Organization for Standardization and International Dairy Federation). 2014. Milk and milk products-Determination of nitrogen content-Part 1: Kjeldahl principle and crude protein calculation. International Standard ISO 8968-1 and IDF 1:2014. ISO, Geneva, Switzerland, and IDF, Brussels, Belgium.

Jõudu, I., M. Henno, T. Kaart, T. Püssa, and O. Kärt. 2008. The effect of milk protein contents on the rennet coagulation properties of milk from individual dairy cows. Int. Dairy J. 18:964-967.

Jõudu, I., M. Henno, S. Värv, T. Kaart, and O. Kärt. 2007. Milk protein genotypes and milk coagulation properties of Estonian Native cattle. Agric. Food Sci. 16:222-231.

Klandar, A. H., A. Lagaude, and D. Chevalier-Lucia. 2007. Assessment of the rennet coagulation of skim milk: A comparison of methods. Int. Dairy J. 17:1151-1160.

Kreuzer, M., A. M. von Siebenthal, A. Kaufmann, H. Ratzer, E. Jakob, and F. Sutter. 1996. Determination of the relative efficacy to enhance milk renneting properties of alterations in dietary energy, breed and stage of lactation. Milchwissenschaft 51:633-637.

Macheboeuf, D., J. B. Coulon, and P. D'Hour. 1993a. Effect of breed, protein genetic variants and feeding on cow's milk coagulation properties. J. Dairy Res. 60:43-54.

Malchiodi, F., A. Cecchinato, M. Penasa, C. Cipolat-Gotet, and G. Bittante. 2014. Milk quality, coagulation properties, and curd firmness modeling of purebred Holsteins and first- and secondgeneration crossbred cows from Swedish Red, Montbéliarde, and Brown Swiss bulls. J. Dairy Sci. 97:4530-4541.

Malossini, F., S. Bovolenta, C. Piras, M. Dalla Rosa, and W. Ventura. 1996. Effect of diet and breed on composition and rennet coagulation properties. Ann. Zootech. 45:29-40.

Mariani, P., and B. Battistotti. 1999. Milk quality for cheesemaking. Recent Progress in Animal Production Science. 1. Pages 499-516 in Proc. APSA XIII Congress, Piacenza, Italy. Franco Angeli s.r.l., Milan, Italy.

Mariani, P., M. Pecorari, and E. Fossa. 1984. Le caratteristiche di coagulazione del latte delle razze Bruna e Frisona nella produzione del formaggio Parmigiano-Reggiano. Pages 319-327 in Atti del XVI Congresso Nazionale della Società Italiana di Buiatria (SIB). SIB, Modena, Italy.

NRC. 2001 Nutrient Requirements of Dairy Cattle. 7th rev. ed. Natl. Acad. Press, Washington, DC.

Oloffs, K., H. Shulte-Coerne, K. Pabst, and H. O. Gravert. 1992. Die Bedeutung der Proteinvarianten für genetische Unterschiede in der Käsereitauglichkeit der Milch. Zuchtungskunde 64:20-26.

Poulsen, N. A., H. P. Bertelsen, H. B. Jensen, F. Gustavsson, M. Glantz, H. Lindmark Mansson, A. Andrén, M. Paulsson, C. Bendixen, A. J. Buitenhuis, and L. B. Larsen. 2013. The occurrence of noncoagulating milk and association of bovine milk coagulation properties with genetic variants of the caseins in 3 Scandinavian dairy breeds. J. Dairy Sci. 96:4830-4842.

Tyrisevä, A. M., K. Elo, A. Kuusipuro, V. Vilva, I. Jänönen, H. Karjalainen, T. Ikonen, and M. Ojala. 2008. Chromosomal regions underlying noncoagulation of milk in Finnish Ayrshire cows. Genetics 180:1211-1220.

Tyrisevä, A.-M., T. Ikonen, and M. Ojala. 2003. Repeatability estimates for milk coagulation traits and non-coagulation of milk in Finnish Ayrshire cows. J. Dairy Res. 70:91-98.

Tyrisevä, A.-M., T. Vahlsten, O. Ruottinen, and M. Ojala. 2004. Noncoagulation of milk in Finnish Ayrshire and Holstein-Friesian cows and effect of herds on milk coagulation ability. J. Dairy Sci. 87:3958-3966.

Vacca, G. M., M. Pazzola, M. L. Dettori, E. Pira, F. Malchiodi, C. Cipolat-Gotet, A. Cecchinato, and G. Bittante. 2015. Modeling of coagulation, curd firming, and syneresis of milk from Sarda ewes. J. Dairy Sci. 98:2245-2259.

Vallas, M., H. Bovenhuis, T. Kaart, K. Parna, H. Kiiman, and E. Pärna. 2010. Genetic parameters for milk coagulation properties in Estonian Holstein cows. J. Dairy Sci. 93:3789-3796. 